\title{
The worldwide epidemiology of acute rheumatic fever and rheumatic heart disease
}

This article was published in the following Dove Press journal:

Clinical Epidemiology

22 February 201I

Number of times this article has been viewed

\section{Michael D Seckeler \\ Tracey R Hoke}

Department of Pediatrics, Division of Cardiology, University of Virginia, Charlottesville, VA, USA
Correspondence: Michael D Seckeler PO Box 800386, University of Virginia, Charlottesville, VA 22908, USA

$\mathrm{Tel}+\mathrm{I}(434)$ 924-9II 9

Fax +I (434) 924-5656

Emailms3ec@hscmail.mcc.virginia.edu
Abstract: Acute rheumatic fever (ARF) and rheumatic heart disease (RHD) are significant public health concerns around the world. Despite decreasing incidence, there is still a significant disease burden, especially in developing nations. This review provides background on the history of ARF, its pathology and treatment, and the current reported worldwide incidence of ARF and prevalence of RHD.

Keywords: rheumatic fever, rheumatic heart disease, group A streptococcus, epidemiology

\section{Introduction}

Acute rheumatic fever (ARF) is a postinfectious, nonsuppurative sequela of pharyngeal infection with Streptococcus pyogenes, or Group A $\beta$ hemolytic Streptococcus (GABHS). Of the associated symptoms, only damage to the valve tissue within the heart, or rheumatic heart disease (RHD), can become a chronic condition leading to congestive heart failure, strokes, endocarditis, and death. While the incidence and prevalence of ARF and RHD have been decreasing in developed nations since the early 1900s, they continue to be major causes of morbidity and mortality among young people in developing nations. It is estimated that there are over 15 million cases of RHD worldwide, with 282,000 new cases and 233,000 deaths annually. ${ }^{1}$

More recent data using echocardiography to screen for RHD in developing nations have lead to a marked increase in the recognized prevalence in these regions. ${ }^{2-6}$ With these new data, there has been an increased awareness and interest in ARF and RHD, which stimulated this review of the literature to provide information on the pathogenesis, diagnosis, and treatment for ARF and RHD, and an updated estimate of the worldwide incidence and prevalence.

\section{Background}

Although physicians in Europe had been describing clinical components of ARF since the 1500s, it was William Charles Wells' seminal publication in 1812 that definitively linked ARF with carditis. ${ }^{7}$ The entire clinical spectrum of ARF (from tonsillitis to carditis) was first described by Cheadle in $1889 .{ }^{8}$ The infectious etiology of ARF was long suspected, especially given the seasonal variation in outbreaks, and in 1900 Poynton and Paine described a diplococcus isolated from patients with ARF, which they implicated as a causal organism for the disease. ${ }^{9}$ Micrococcus (or Streptococcus) rheumaticus was isolated from a patient with ARF in 1904, and was noted to be "indistinguishable from strains of Streptococcus pyogenes" ${ }^{10}$ Into the 1930 s, theories implicating viruses as causal agents for ARF surfaced, ${ }^{11}$ and are still being investigated today. ${ }^{12,13}$ 


\section{Methods}

An extensive literature search for any articles about "acute rheumatic fever" or "rheumatic heart disease" was performed in August 2010 using PubMed. Articles reporting data of the incidence of ARF or prevalence of RHD were reviewed. In order to maximize the available information, non-English language articles were included if it was possible to obtain an English translation of either the abstract or the entire article.

To generate trends of ARF incidence and RHD prevalence over time, data from various countries were clustered by World Health Organization (WHO) region - Africa, the Americas, Southeast Asia, Europe, Eastern Mediterranean, and Western Pacific. Data reported from any countries within a WHO region for a given year were averaged together to provide a value for that year. These data were plotted for the time period 1970 to 2009 , and trend lines were calculated with quadratic regression for each WHO region and are reported in the graphs. Regional incidence and prevalence estimates were not weighted by the underlying population.

The last major WHO report on the worldwide prevalence of ARF and RHD reported data through $1990 .{ }^{14}$ This year was used as a cutoff to create 2 eras: 1970 through 1990 , and 1991 through the present. ARF incidence and RHD prevalence rates for each reporting country during these eras were graded and plotted on a world map to show the changes in disease burden and geographic location with time in more detail than the trend plots.

Jones criteria for each of the WHO regions were compared using one way ANOVA with post-hoc analysis to identify significant differences in criteria between regions.

\section{Diagnosis}

The diagnostic criteria for ARF were first developed by Jones in $1944^{15}$ and have since been modified in $1965,{ }^{16} 1984,{ }^{17}$ $1992,{ }^{18}$ and $2002 .{ }^{19}$ The criteria are divided into Major and Minor criteria (Table 1). Diagnosis is made by the presence of either 2 Major or 1 Major and 2 Minor criteria, plus evidence of recent streptococcal infection, either by a pharyngeal swab

Table I Major and Minor Jones criteria for the diagnosis of acute rheumatic fever ${ }^{18}$

\begin{tabular}{ll}
\hline Major criteria & Minor criteria \\
\hline Migratory polyarthritis & Arthralgia \\
Carditis & Fever \\
Erythema marginatum & First degree heart block \\
Syndenham chorea & Elevated inflammatory markers (ESR, CRP) \\
Subcutaneous nodules & \\
\hline Abbreviations: CRP, C-reactive protein; ESR, erythrocyte sedimentation rate.
\end{tabular}

culture positive for GABHS, positive rapid GABHS antigen test or rising serologic antibody titers (antistreptolysin O [ASO], DNAse B, or streptokinase). ${ }^{18}$

The Major criteria are migratory polyarthritis, carditis, Sydenham chorea, erythema marginatum, and subcutaneous nodules. Polyarthitis is redness, swelling, and intense pain of multiple, usually large, joints that can change from one location to another as the disease progresses. Carditis is typically valvulitis and has traditionally been diagnosed by a new murmur suggestive of valvar regurgitation, but echocardiography has been used more in recent years to aid in the diagnosis (see below). There may be myocarditis or pericarditis in addition to the valvulitis. Sydenham chorea, or St. Vitus' dance, is rapid, uncontrolled movements of the trunk or extremities. There can also be worsening school performance, behavioral changes, and emotional lability. Erythema marginatum is a transient rash with central pallor and red, serpiginous (snake-like) borders found on the trunk and extremities. Subcutaneous nodules are painless, fleshcolored bumps, usually found on the extensor surfaces of the arms and legs. ${ }^{18}$

The Minor criteria are arthralgias, fever, elevated acutephase reactants, and first degree heart block. Arthralgia is pain, often in multiple joints, without associated redness or swelling. Of note, a patient can have either arthritis or arthralgia as a Jones criterion, but not both. Fever, usually at least $39^{\circ} \mathrm{C}$, is common in early ARF. Acute-phase reactants are nonspecific laboratory markers of inflammation in the body. The typical ones measured are erythrocyte sedimentation rate (ESR) and C-reactive protein (CRP), both of which are expected to be elevated during an episode of ARF. These markers can also be followed as signs of resolution of ARF. First degree heart block is diagnosed by prolongation of the PR interval on electrocardiogram (Figure 1). Having first degree heart block does not predict whether a patient will develop RHD. ${ }^{18}$

There has been controversy over the use of Doppler echocardiography in the diagnosis of ARF. ${ }^{19,20}$ Many argue

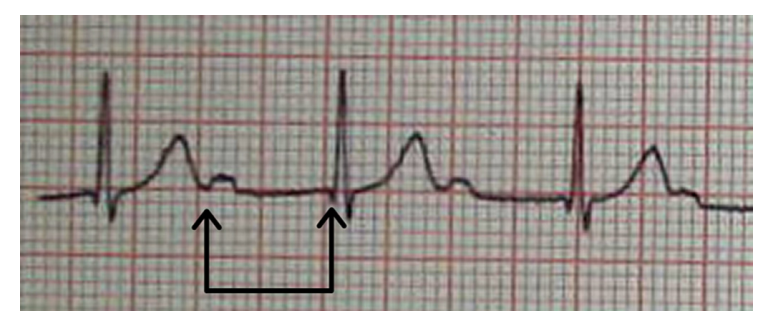

Figure I Electrocardiogram demonstrating first-degree heart block in a patient with acute rheumatic fever. The PR interval is noted by the arrows, and is markedly prolonged at $\mathbf{3 0 0}$ milliseconds (normal for an adult is less than $\mathbf{2 0 0}$ milliseconds). 
that echocardiography can help to diagnosis subclinical RHD, especially among high-risk populations. ${ }^{21-24}$ However, since it is not known how much valvar regurgitation is "normal", there is concern for overdiagnosis of carditis by relying on Doppler echocardiography. ${ }^{19}$ The current American Heart Association guidelines recommend the use of Doppler echocardiography as a supplement to diagnosis, but evidence of valvar regurgitation should not be used as a Major or Minor criterion.

\section{Pathophysiology}

Even though ARF has been recognized as a disease entity for at least 150 years, a clear understanding of the pathophysiology still eludes modern physicians. The role of GABHS infection as an initial event is clear, and has been supported by outbreaks of ARF following outbreaks of pharyngitis, as well as rising antistreptococcal antibodies in patients with ARF. ${ }^{25} \mathrm{ARF}$ is believed to be an autoimmune reaction to GABHS infection. Genetically determined host susceptibility has long been presumed, especially given the tendency for outbreaks to occur within families and the relatively few cases of ARF that develop given the high prevalence of GABHS pharyngitis and pharyngeal carriage. ${ }^{26}$ Many studies have investigated the role of HLA alleles, which are located on chromosome 6, in ARF susceptibility, and while there have been no universal associations, HLADR7 has been the most frequently associated with ARF and RHD. ${ }^{27-45}$

While the exact mechanism by which certain genes can confer an increased susceptibility to ARF has not been delineated, there are theories about the roles played. HLA molecules process antigens within a host cell and present them on the cell surface to T cells, which can then attack the antigen or activate B cells to produce antibodies to the antigen. If the HLA molecules present antigens that resemble both Streptococcus and human tissues, then host cells can be attacked. This is called molecular mimicry and will be discussed more below. Another protein that has been associated with ARF and RHD is the inflammatory cytokine, tumor necrosis factor- $\alpha$ (TNF- $\alpha)$, which is also located on chromosome 6 near the HLA alleles. TNF- $\alpha$ may be upregulated in patients with increased ARF susceptibility, leading to an increased inflammatory response in these patients, and subsequent development of ARF. ${ }^{30} \mathrm{~A}$ third factor, mannose-binding lectin (MBL), binds to various sugar molecules on the cell surface and helps to mark foreign cells for immune cells to eliminate. RHD patients with mitral valve damage have been found to have high levels of MBL in their blood, while those with aortic valve damage have low levels. ${ }^{30}$

The theory of cross-reaction between GABHS and heart tissue has been explored for at least 60 years. Cavelti first identified anticardiac autoantibodies in ARF in 1945, and subsequently demonstrated that anticardiac and antiskeletal muscle antibodies were produced in rats, but only in the presence of killed streptococci. ${ }^{46,47}$ These antibodies could subsequently react to, and damage, host tissue without the continued need for streptococci to be present. ${ }^{48}$ In 1962 , Kaplan and colleagues demonstrated a cross-reactivity between human heart tissue and $\mathrm{GABHS}^{49}$ and later anticardiac antibodies in patients with ARF. ${ }^{50}$ Further study has led to the identification of the M-protein on the GABHS cell membrane as the likely antigen for inducing the production of antibodies that cross-react with human heart tissue.

The cross-reactivity is believed to occur through molecular mimicry, where all or part of a foreign antigen resembles at least some portion of host tissue. In ARF and RHD, the foreign antigen is the M-protein and it cross reacts with cardiac myosin, which induces T-cell mediated attack of the heart tissue and valves. Once valve tissue is damaged and inflamed, proteins that are normally intracellular can become exposed to invading immune cells and lead to the development of more autoantibodies directed at different component proteins of valve tissue. ${ }^{30}$ This leads to further inflammation and scarring of heart valve tissue and chronic RHD. All four heart valves can be involved in rheumatic carditis; however there is a marked predominance of mitral valve involvement. This has recently been associated with higher levels of MBL, ${ }^{30}$ but is not clear why more MBL leads to damage of the mitral valve. Since all heart valves develop from the same tissue, they should be equally susceptible to attack from an autoantibody. ${ }^{51}$

Once heart valves have been damaged, they do not function properly, and blood is allowed to leak backward, or regurgitate. In severe cases, this can cause acute congestive heart failure, which can be the presenting symptom of ARF. Figure $2 \mathrm{a}$ shows normal cardiac anatomy and Figures $2 \mathrm{~b}$ and $2 \mathrm{c}$ show echocardiograms demonstrating a thickened, regurgitant mitral valve. In addition to the usual treatment for ARF, these patients require medical management for their heart failure. Patients that recover from the initial rheumatic carditis are likely to have permanent valve damage, and over time the affected valves can become stenotic in addition to regurgitant. Severe valve stenosis or regurgitation can eventually warrant surgical repair or replacement of 


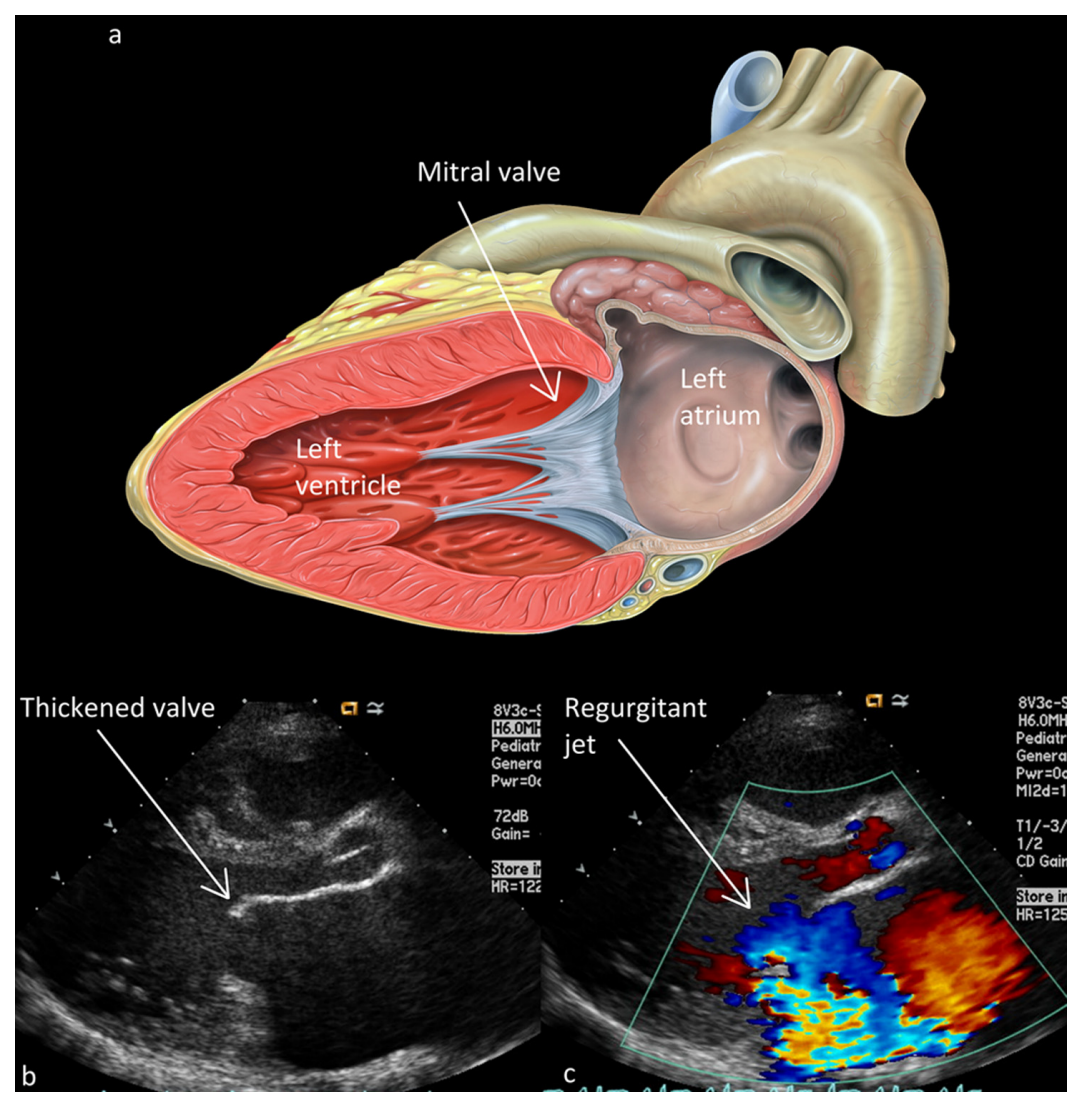

Figure 2 a) Artist rendition of normal left heart anatomy, demonstrating the left atrium connected to the left ventricle via a mitral valve. $\left.{ }^{52} \mathbf{b}\right)$ Two-dimensional echocardiogram of the left heart, demonstrating a thickened anterior leaflet of the mitral valve. c) Two-dimensional echocardiogram with color Doppler, demonstrating moderate-to-severe mitral valve regurgitation (blue jet).

the affected heart valves. A recent review of 361 cardiac surgeries for rheumatic disease (RHD, neonatal lupus, systemic lupus, Kawasaki disease, or juvenile rheumatoid arthritis) among 261 North American patients from 1985 to 2005 found that $55 \%$ of the surgeries were for RHD (160 patients, 200 procedures) with 3 in-hospital deaths..$^{53}$ In various series of patients with endocarditis, RHD was the underlying cause in $15 \%$ to $76.6 \%$ of cases, with mortality from endocarditis ranging from $29 \%$ to $36 \% .{ }^{54-57}$ The cost of surgical intervention for RHD is approximately US $\$ 25,000$, which is enough to fund 1 year of an RHD screening program in a small developing nation. ${ }^{58}$ Early detection of ARF and RHD through screening programs can reduce the morbidity of chronic RHD and surgeries for heart valve repair or replacement.

There appears to be molecular mimicry involved in the development of Syndeham chorea as well. Numerous studies have provided evidence for anti-neuronal antibodies to the basal ganglia in patients with Sydenham chorea.$^{59}$ Kirvan and colleagues recently found a carbohydrate component of the streptococcal cell wall that cross-reacts with gangliosides in the cell membrane of neurons in the basal ganglia. Not only does this cause inflammation and damage neurons, but since gangliosides are involved in cell signaling, neuronal pathways can be disrupted as well. ${ }^{60}$ One function of the basal ganglia is inhibition of motor impulses. Damage to this area can explain the unusual movements associated with Sydenham chorea.

Investigators have used MRI to examine the brains of patients with Sydenham chorea to determine the etiology of the movement, speech and behavioral issues. One of the earliest reports of brain MRI findings in acute Sydenham chorea demonstrated increased signal intensity in the caudate nucleus, a component of the basal ganglia, with associated edema and shifting of brain matter. ${ }^{61}$ This appeared to correlate with pathologic findings seen in varying case series which show blood vessel inflammation, occlusion and necrosis in early disease, and degenerative changes in recurrent chorea. ${ }^{61,62}$ Subsequent case series have demonstrated acute changes in the caudate nucleus (some of which progressed to cystic changes on subsequent studies ${ }^{63}$ and others with lesions in the subcortical white matter, which may be the cause of speech and behavioral symptoms. ${ }^{64}$ 
Table 2 Antibiotic regimens for treatment of group A streptococcal pharyngeal infections.

\begin{tabular}{|c|c|c|}
\hline Antibiotic & Dose & Duration \\
\hline Penicillin V & $\begin{array}{l}250 \mathrm{mg} \text { by mouth } 2 \text { to } 3 \\
\text { times daily }(\leq 27 \mathrm{~kg}) \text { or } \\
500 \mathrm{mg} \text { by mouth } 2 \text { to } 3 \\
\text { times daily }(>27 \mathrm{~kg})\end{array}$ & 10 days \\
\hline $\begin{array}{l}\text { Benzathine } \\
\text { penicillin G }\end{array}$ & $\begin{array}{l}600,000 \text { units intramuscular } \\
(\leq 27 \mathrm{~kg}) \text { or } \\
1,200,000 \text { units intramuscular } \\
(>27 \mathrm{~kg})\end{array}$ & Once \\
\hline Amoxicillin & $50 \mathrm{mg} / \mathrm{kg}$ by mouth daily & 10 days \\
\hline $\begin{array}{l}\text { Cephalosporin } \\
\text { (first generation) }\end{array}$ & Drug-dependent & 10 days \\
\hline Clindamycin $^{\mathrm{a}}$ & $\begin{array}{l}20 \mathrm{mg} / \mathrm{kg} / \text { day divided in } \\
3 \text { doses by mouth }\end{array}$ & 10 days \\
\hline Clarithromycin $^{a}$ & $\begin{array}{l}15 \mathrm{mg} / \mathrm{kg} / \text { day divided } \\
\text { in } 2 \text { doses by mouth }\end{array}$ & 10 days \\
\hline Azithromycin ${ }^{a}$ & $12 \mathrm{mg} / \mathrm{kg}$ by mouth daily & 5 days \\
\hline
\end{tabular}

Notes: aln penicillin-allergic patients. Note, up to $5 \%$ of patients allergic to penicillin may also be allergic to cephalosporins.

Source: American Heart Association, Inc. ${ }^{66}$

\section{Treatment}

\section{Primary prevention}

There are several approaches to reduce the impact of ARF. The first line is primary prevention through the recognition of GABHS pharyngitis and treatment with appropriate antibiotics. Antibiotic therapy initiated within 9 days of onset of pharyngitis is effective in preventing ARF. ${ }^{65,66}$ Oral penicillin V is still the first line treatment in patients whom compliance can be expected, and there has never been documentation of GABHS isolates that are resistant to penicillin. For patients in whom compliance with an oral regimen is a problem, a single intramuscular dose of benzathine penicillin $\mathrm{G}$ (BPG) can be given at the time of GABHS pharyngitis diagnosis. Patients that have a hypersensitivity to penicillin may be treated with a first-generation cephalosporin, but as many as 5\% may also be allergic to cephalosporins. Macrolides, including erythromycin, clarithromycin, and azithromycin, are another alternative, although there have been GABHS strains that demonstrate macrolide resistance. Fluoroquinolones, tetracyclines, and sulfonamides are not recommended to treat GABHS pharyngitis. ${ }^{65,66}$ Full details of antibiotic treatments for GABHS pharyngitis are shown in Table 2.

Another intriguing area of research for the past 40 years in ARF prevention is GABHS vaccine development. While there are many potential vaccine candidates, the extracellular M-protein on the surface of GABHS cells has become the primary target, and there are currently 4 vaccines in development targeting the M-protein. ${ }^{67,68}$ Part of the complexity in vaccine development is the high variability

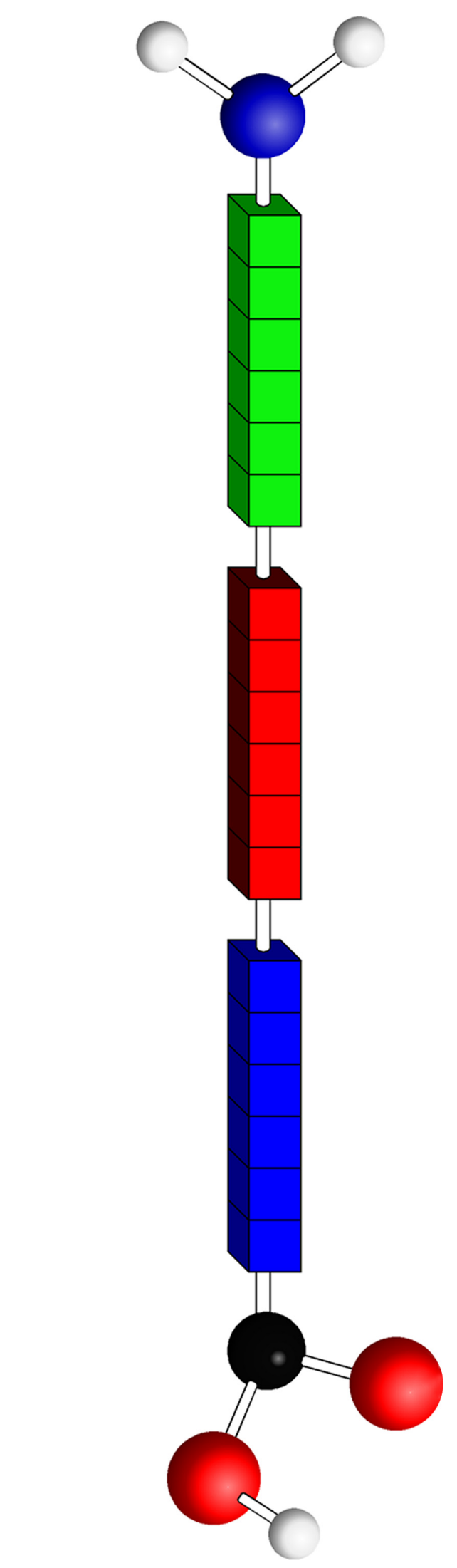

Figure 3 Schematic drawing of the M-protein structure with the conserved (blue), variable (red), and hypervariable (green) regions. Note that the conserved region is closest to the cell membrane. 
of the M-proteins, with over 150 M-types identified. Figure 3 shows a schematic of the structure of the M-protein, with conserved, variable, and hypervariable regions. The hypervariable region is exposed to the host immune system and is the portion that distinguishes each M subtype. For the 26-valent GABHS vaccine, the decision about which M-types to include was based on the United States Centers for Disease Control's Active Bacterial Core Surveillance of the Emerging Infections Program Network. The 26 chosen strains were those associated with pharyngitis, invasive disease, and ARF, so-called "rheumatogenic" strains. ${ }^{69}$ It is important to note that these strains are based only on data from the United States, which will be discussed more later. The other three M-protein-based vaccines in development target the conserved region of the M-protein, and are likely to provide protection against a wider range of M-types. ${ }^{68}$ Since ARF is thought to be due to an autoimmune response to the M-protein and molecular mimicry of the heart valve tissue, there is concern that vaccination could actually cause ARF. This was seen in an early M-protein vaccine trial in the 1960s where all patients receiving the vaccine developed antistreptococcal antibodies, but 3 of 21 also developed ARF, compared to 5 of 447 controls..$^{70,71}$

\section{Acute treatment}

Salicylate therapy for the symptoms of ARF was first attempted successfully by Maclagan in $1876 . .^{72,73}$ Since then, a variety of treatments have also been attempted for ARF, including irradiation of the heart, ${ }^{74}$ administration of ascorbic acid and orange juice, ${ }^{75}$ or heparin, ${ }^{76}$ and prolonged confinement to a hyperoxic chamber. ${ }^{77}$ While aspirin has remained the mainstay of ARF therapy, the exact action of effect is unclear, but seems to be related to the anti-inflammatory properties. This has prompted the study of other anti-inflammatory medications.

Table 3 Antibiotic regimen for secondary prophylaxis of acute rheumatic fever.

\begin{tabular}{ll}
\hline Antibiotic & Dose \\
\hline Benzathine penicillin G & 600,000 units intramuscular $(\leq 27 \mathrm{~kg})$ or \\
& $\mathrm{I}, 200,000$ units intramuscular $(>27 \mathrm{~kg})$ \\
& Every 4 weeks (3 weeks in high-risk \\
& areas/populations) \\
& $250 \mathrm{mg}$ by mouth twice daily \\
Penicillin V & $0.5 \mathrm{~g}$ by mouth daily $(\leq 27 \mathrm{~kg})$ or \\
Sulfadiazine & I g by mouth daily $(>27 \mathrm{~kg})$ \\
& Drug-dependent \\
\hline
\end{tabular}

Notes: an penicillin-allergic patients. Note, up to $5 \%$ of patients allergic to penicillin may also be allergic to cephalosporins.

Source: American Heart Association, Inc. ${ }^{66}$
A large multi-center study in the United States and United Kingdom in 1955 compared the efficacy of aspirin, cortisone, and adrenocorticotropic hormone for the acute treatment of the symptoms of ARF. They found that there was no difference in final outcomes; the hormonal treatments caused more rapid resolution of some symptoms, but at the cost of higher recurrence rates. ${ }^{78} \mathrm{~A}$ more recent meta-analysis confirmed these results and found no significant reduction in the development of RHD with corticosteroids compared to aspirin. ${ }^{79}$ Given the higher likelihood of side effects from steroid treatment, aspirin has remained the first line treatment for uncomplicated ARF. ${ }^{21}$ Treatment with aspirin usually causes marked improvement in the joint manifestations of ARF within 24 to 48 hours, which can help distinguish ARF from other arthritides which do not resolve as quickly. For those who cannot tolerate aspirin, naproxen has been used as an alternative anti-inflammatory agent. ${ }^{80,81}$ Some groups do recommend the use of corticosteroids for carditis in patients who are in severe heart failure. ${ }^{21,22}$ Anti-inflammatory medications are given until the inflammatory markers normalize, usually 4 to 6 weeks.

There have been studies showing decreased severity and duration of chorea with prednisone therapy. ${ }^{82} \mathrm{Paz}$ and colleagues $^{82}$ performed a placebo-controlled study on a group of 37 children with Sydenham chorea, treated 22 with prednisone, and found a quicker resolution of chorea symptoms in the treatment group. Given the inflammatory changes seen on pathologic specimens, ${ }^{61,62}$ corticosteroid treatment for chorea is a logical choice. However, the progression to degenerative changes seen in recurrent chorea makes corticosteroids less likely to be of any benefit in this group.

\section{Secondary prophylaxis}

Those patients who develop ARF are at high risk to develop subsequent attacks when infected with GABHS, and so this population is best treated with secondary antibiotic prophylaxis after their initial attack (Table 3). Patients who have recurrences of ARF are at risk to develop carditis, if they had not already, or worsen existing valve damage. Antibiotic choices are similar to those for GABHS pharyngitis. Secondary antibiotic prophylaxis is only effective when there is high compliance, ${ }^{66,83}$ so many healthcare providers prescribe intramuscular BPG every 4 weeks to ensure adequate serum penicillin levels. Studies in areas highly endemic for ARF have found that BPG dosed every 3 weeks provides better prevention of recurrent ARF. ${ }^{84}$ If patients are compliant with oral regimens, these can be equally effective.

Secondary antibiotic prophylaxis should be given to individuals most at risk for GABHS pharyngeal infections. These include children, people living in crowded conditions 
Table 4 Reported incidence of acute rheumatic fever (ARF) (per 100,000 persons) from 1930 through 1970

\begin{tabular}{|c|c|c|c|}
\hline Years & Country & Subgroup & ARF $(/ 100,000)$ \\
\hline $1930-1964$ & Sweden ${ }^{85}$ & & $25 \rightarrow \mathrm{I} .3$ \\
\hline \multirow[t]{2}{*}{$1935-1949$} & United States & & $35-65$ \\
\hline & $(\text { Minnesota })^{86}$ & & \\
\hline \multirow[t]{2}{*}{$1948-1953$} & England & & $25.5-55$ \\
\hline & (Bristol/Sheffield) $^{87}$ & & \\
\hline \multirow[t]{2}{*}{$|949-196|$} & United States & & $12-14$ \\
\hline & (Colorado) $^{88}$ & & \\
\hline 1950 & Costa Rica ${ }^{89}$ & & 120 \\
\hline 1952 & Peru 90 & & 27 \\
\hline $1952-1957$ & Sri Lanka" & & 112 \\
\hline \multirow[t]{2}{*}{$1960-1964$} & United States & & 15.6 \\
\hline & $(\text { Maryland })^{92}$ & & \\
\hline \multirow[t]{2}{*}{$1960-1964$} & United States & & $4.7-6.4$ \\
\hline & $(U \text { tah })^{93}$ & & \\
\hline \multirow[t]{2}{*}{$1963-1965$} & United States & African & 47 \\
\hline & $(\text { New York })^{94}$ & Americans & \\
\hline \multirow[t]{2}{*}{$1963-1965$} & United States & Puerto Ricans & 78 \\
\hline & $\left(\right.$ New York) ${ }^{94}$ & & \\
\hline \multirow[t]{2}{*}{$1963-1965$} & United States & Whites & 23 \\
\hline & $\left(\right.$ New York) ${ }^{94}$ & & \\
\hline \multirow[t]{2}{*}{$1963-1969$} & United States & African & 44.4 \\
\hline & $(\text { Tennessee })^{95}$ & Americans & \\
\hline \multirow[t]{2}{*}{$1963-1969$} & United States & Whites & 21.9 \\
\hline & $(\text { Tennessee })^{95}$ & & \\
\hline 1966 & Denmark $^{85}$ & & 1.5 \\
\hline $1965-1966$ & Fiji ${ }^{6}$ & Fijians & 13 \\
\hline $1965-1966$ & $\mathrm{Fiji}^{96}$ & Indians & 140 \\
\hline \multirow[t]{2}{*}{1970} & United States & Papago tribe & 92 \\
\hline & $(\text { Arizona })^{97}$ & & \\
\hline
\end{tabular}

(military recruits, college students), parents, teachers, and healthcare workers. The American Heart Association guidelines state that individuals who have had ARF without carditis should be treated until the age of 21 years or 5 years after their last attack, whichever is longer. Those with RHD should be treated until 40 years of age or 10 years after their last attack, whichever is longer. The most important component of these guidelines is the need to assess each patient's clinical situation to determine if they have continued high-risk exposure to GABHS which could warrant lifelong prophylaxis. It is also recommended to continue prophylaxis after heart valve

Table 5 Reported prevalence of rheumatic heart disease (RHD) (per 1000 persons) from 1935 through 1970

\begin{tabular}{lll}
\hline Years & Country & RHD (/I000) \\
\hline $1935-1964$ & United States (Minnesota) & $20.6 \rightarrow 12$ \\
$1949-1951$ & United States (Colorado) & 6.7 \\
$1958-1961$ & Japan $^{88}$ & $4.6 \rightarrow 2.1$ \\
1961 & USSR $^{99}$ & $10-30$ \\
$1964-1965$ & Pakistan (Karachi) $^{100}$ & 1.8 \\
1966 & India (Chandigarh) & 1.8 \\
1970 & Taiwan (Taipei) $^{102}$ & 1.4 \\
1970 & Uruguay $^{103}$ & 1 \\
\hline
\end{tabular}

replacement surgery, as any of the four cardiac valves can be affected by ARF. ${ }^{65,66}$

\section{Results}

Of the 164 articles reviewed for ARF incidence and RHD prevalence data, 85 utilized population-based screening, national health registries, prospective disease surveillance, surgical series, or autopsy series. Seventy-nine studies were retrospective reviews of hospital admissions or discharges for ARF or RHD, data from specialty referral clinics, or studies from which the data collection methods could not be determined. In order to maximize the available data, all studies were included.

The literature review revealed data on the incidence and/or prevalence of ARF and RHD in 100 countries around the world. Tables 4 and 5 show the reported incidence of ARF and prevalence of RHD for the era before 1970. Figures 4 through 7 present the incidence of ARF and prevalence of RHD during the 1970 to 1990 and 1991 to present eras.

Figures 8 and 9 are graphs of the trend of ARF incidence and RHD prevalence for each WHO Region. The reported incidence of ARF is decreasing in all WHO Regions except for the Americas where it appears to be increasing slightly and the Western Pacific, where it appears to be steadily increasing. The reported prevalence of RHD is increasing in all regions except for Europe, where it appears to be decreasing.

Table 6 shows the percentages of patients with the Major and Minor criteria for each WHO region and for all reported studies combined. There was a slight male predominance in all ARF cases, and the only significant difference between regions was a higher male predominance in Southeast Asia compared to the Western Pacific $(P=0.049)$. Overall, carditis occurred in $60 \%$ of cases, but the Americas had significantly fewer cases than the Western Pacific or Southeast Asia ( $P=0.005$ and 0.019 , respectively). Arthritis also occurred in $60 \%$ of all cases and Southeast Asia had significantly fewer cases than the Americas, Europe and the Eastern Mediterranean $(P=0.002,0.011$ and 0.013 , respectively). There were more cases of erythema marginatum in the Americas than in Southeast Asia $(P=0.015)$, and in the Western Pacific than in both the Eastern Mediterranean and Southeast Asia $(P=0.015$ and 0.003 , respectively). The Americas also had more cases of chorea than the Eastern Mediterranean $(P=0.025)$. Fever and an elevated ESR were reported less often in Africa than any of the other regions, and ESR elevation was less in Southeast Asia than in the Eastern Mediterranean and Western Pacific ( $P=0.019$ and 0.041 , respectively). Elevated 


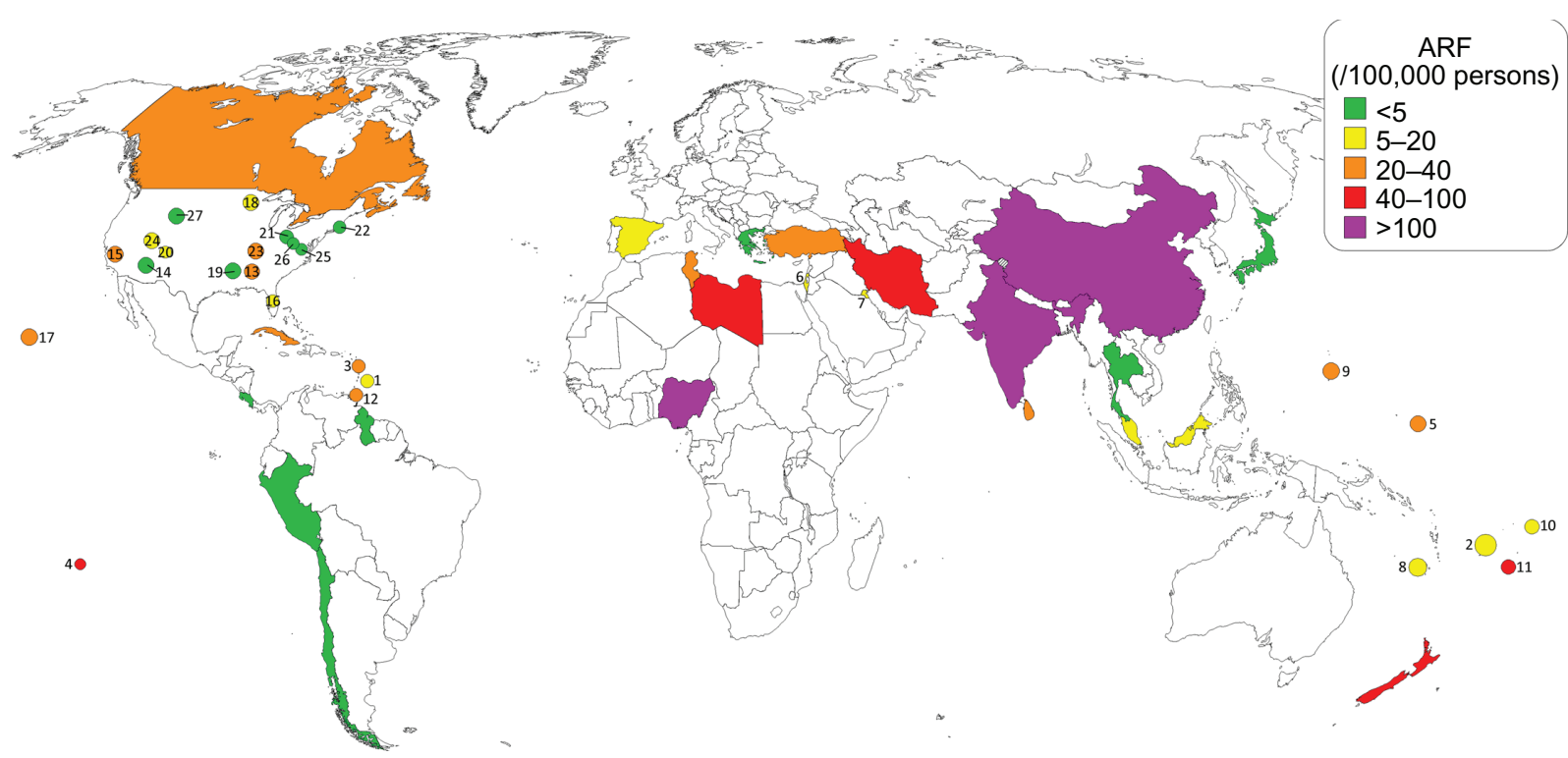

Figure 4 Map showing reported worldwide incidence of ARF from 1970 through 1990.86,97,104-156 (I) Barbados, ${ }^{104,105}$ (2) Fiji, ${ }^{12}$ (3) French Antilles, ${ }^{113}$ (4) French Polynesia, ${ }^{112}$ (5) Federated States of Micronesia, ${ }^{114}$ (6) Israel, ${ }^{120}$ (7) Kuwait, ${ }^{123-125}$ (8) New Caledonia, ${ }^{112}$ (9) Northern Mariana Islands, ${ }^{133}$ (10) Samoa, ${ }^{112}$ (II) Tonga, ${ }^{112,136}$ (I2) Trinidad, ${ }^{137}$ (13) Alabama, ${ }^{140}$ (14) Arizona, ${ }^{97}$ (I5) California, ${ }^{14,142}$ (16) Florida, ${ }^{143}$ (I7) Hawaii, ${ }^{14-146}$ (18) Minnesota, ${ }^{86}$ (19) Mississippi, ${ }^{147}$ (20) Navajo Reservation, ${ }^{148}$ (2I) Ohio, ${ }^{149,150}$ (22) Rhode Island, ${ }^{151}$ (23) Tennessee, ${ }^{152}$ (24)Utah, ${ }^{93}$ (25) Virginia, ${ }^{153}$ (26) West Virginia, ${ }^{154,155}$ (27) Wyoming. ${ }^{97}$

ASO titer was more common in the Americas, Europe, Eastern Mediterranean, and Western Pacific than in Africa ( $P=0.002,0.022,<0.001$, and 0.036 , respectively), and in the Americas and Eastern Mediterranean than in Southeast Asia $(P=0.026$ and 0.005 , respectively). Regional ARF recurrence rates ranged from $8 \%$ to $34 \%$, with Europe having significantly fewer recurrences than the Americas, Eastern Mediterranean, Western Pacific, and Southeast Asia $(P=0.013,0.004,0.025$, and 0.001 , respectively); Africa had fewer recurrences than Southeast Asia $(P=0.049)$. There was no difference in subcutaneous nodules, arthralgia, or first-degree heart block between all 6 regions. There were not enough data available to compare differences in Major and Minor criteria between the two eras to evaluate for changes in presenting Jones criteria over time.

The reported M-types are presented in Figure 10, showing M-types from developing nations (Figure 10a), developed nations (Figure 10b), and both combined (Figure 10c). For

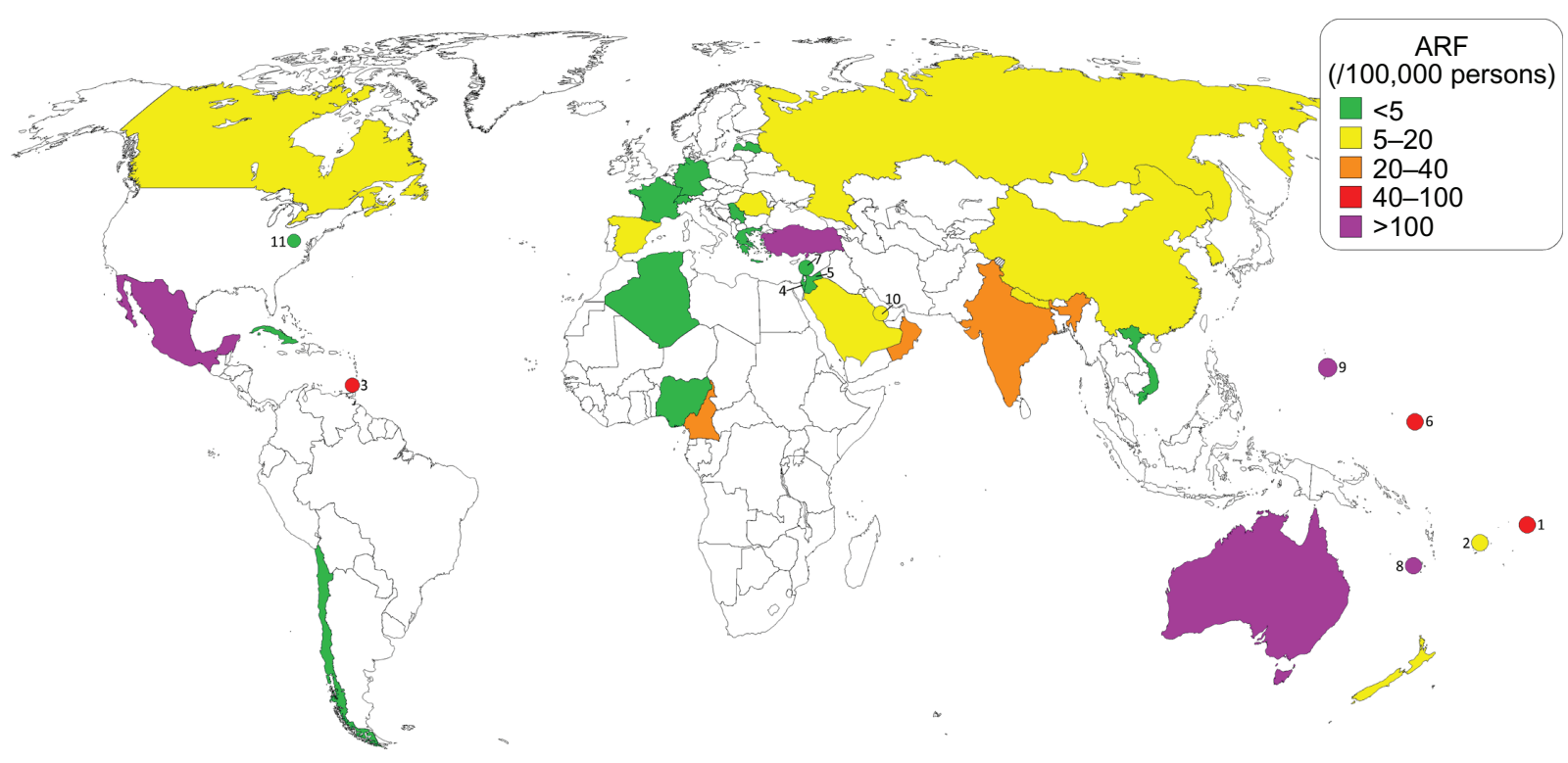

Figure 5 Map showing reported worldwide incidence of ARF from 1991 through present. ${ }^{40,108,111,115,120,139,156-200}$ (I) American Samoa, ${ }^{159,192}$ (2) Fiji, ${ }^{169-171}$ (3) Grenada, ${ }^{175}$ (4) Israel, ${ }^{120,178}$ (5) Jordan, ${ }^{179}$ (6) Kosrae, Federated States of Micronesia, ${ }^{181}$ (7) Lebanon, ${ }^{182}$ (8) New Caledonia, ${ }^{185}$ (9) Northern Mariana Islands, ${ }^{133}$ (I0) Qatar, ${ }^{190}$ (II) West Virginia. ${ }^{199}$ 


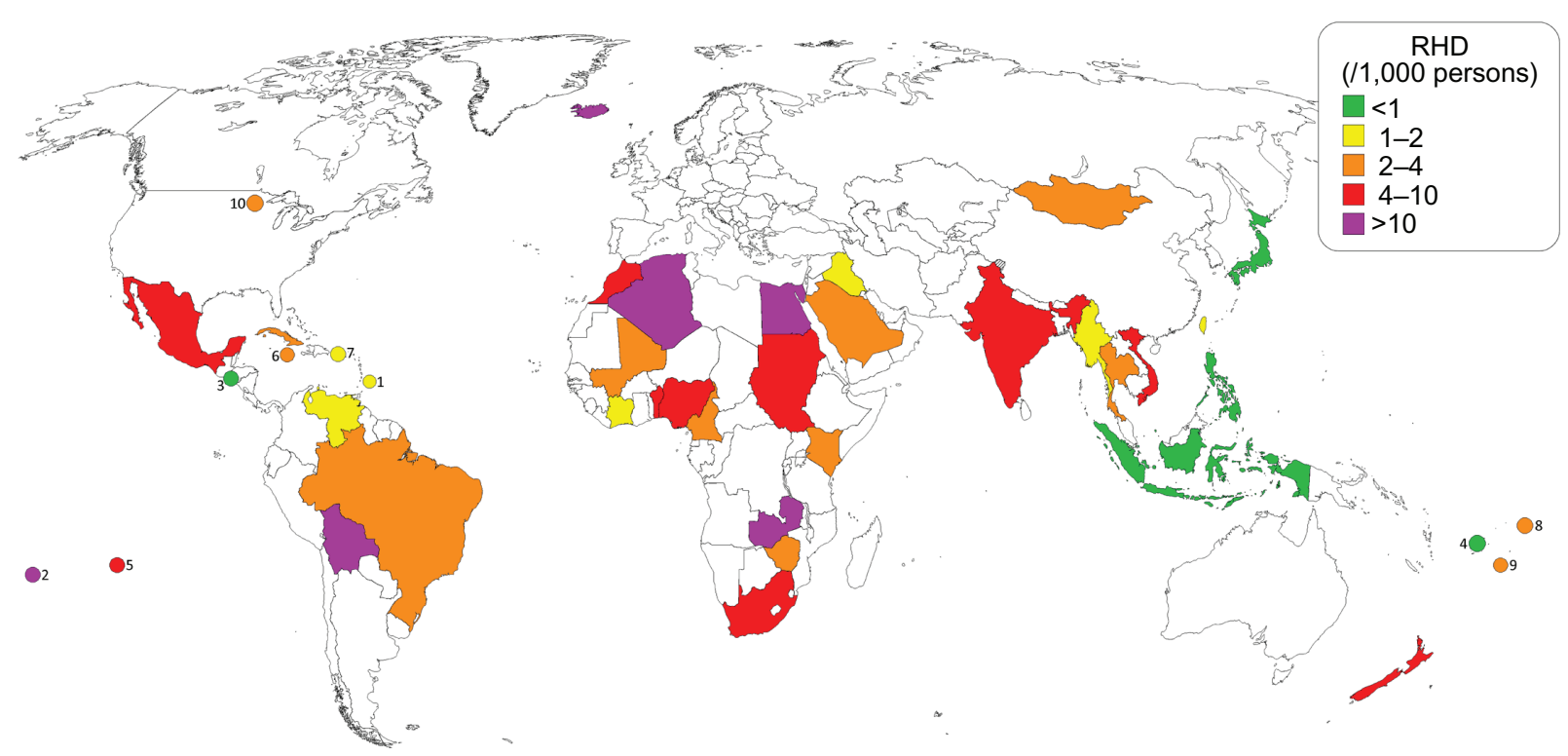

Figure 6 Map showing reported worldwide prevalence of RHD from 1970 through 1990.14,21,86,90,99,102-104,111,112,118,128,132,136,201-216 (I) Barbados, ${ }^{104}$ (2) Cook Islands, ${ }^{21}$ (3) El Salvador, ${ }^{202}$ (4) Fiji, ${ }^{112}$ (5) French Polynesia, ${ }^{112}$ (6) Jamaica, ${ }^{202}$ (7) Puerto Rico, ${ }^{103}$ (8) Samoa, ${ }^{112}$ (9) Tonga, ${ }^{112,136}$ (10) Minnesota. ${ }^{86}$

comparison, in Figure 10 the 26 M-types present in the GABHS vaccine currently being tested are noted by an asterisk. ${ }^{69,241}$

\section{Discussion}

This is the most comprehensive review of the incidence and prevalence of ARF and RHD in the English literature to date. The inherent limitations to the methods of many reviewed studies, especially those presenting data from specialty referral clinics or hospital admissions, do not allow calculation of exact incidence rates. However, these data make clear that ARF and RHD still exist in significant numbers around the world, which is a disappointment from a public health standpoint.

As might be expected, practice patterns for ARF diagnosis vary across countries. In Africa, where public health resources are limited, only $50 \%$ of patients diagnosed with ARF had laboratory evidence of a recent streptococcal infection demonstrated by an elevated or rising ASO titer. All patients diagnosed with ARF were treated accordingly.

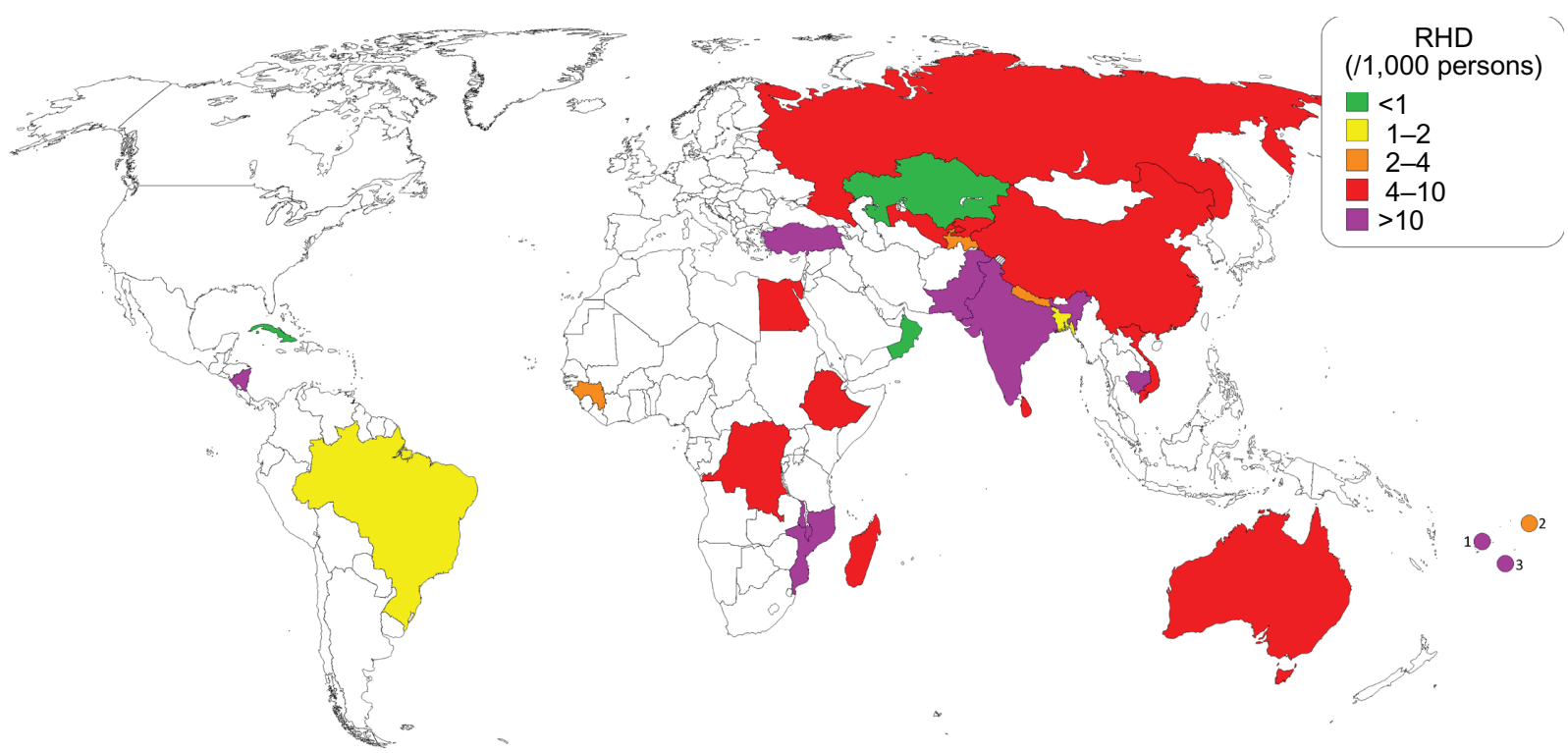

Figure 7 Map showing reported worldwide prevalence of RHD from I99| through present. ${ }^{2-6,21,111,160,168,169,176,177,189,191,192,197,217-240}$ (I) Fiji, ${ }^{169,228}$ (2) Samoa, ${ }^{192}$ (3) Tonga. ${ }^{3}$ 

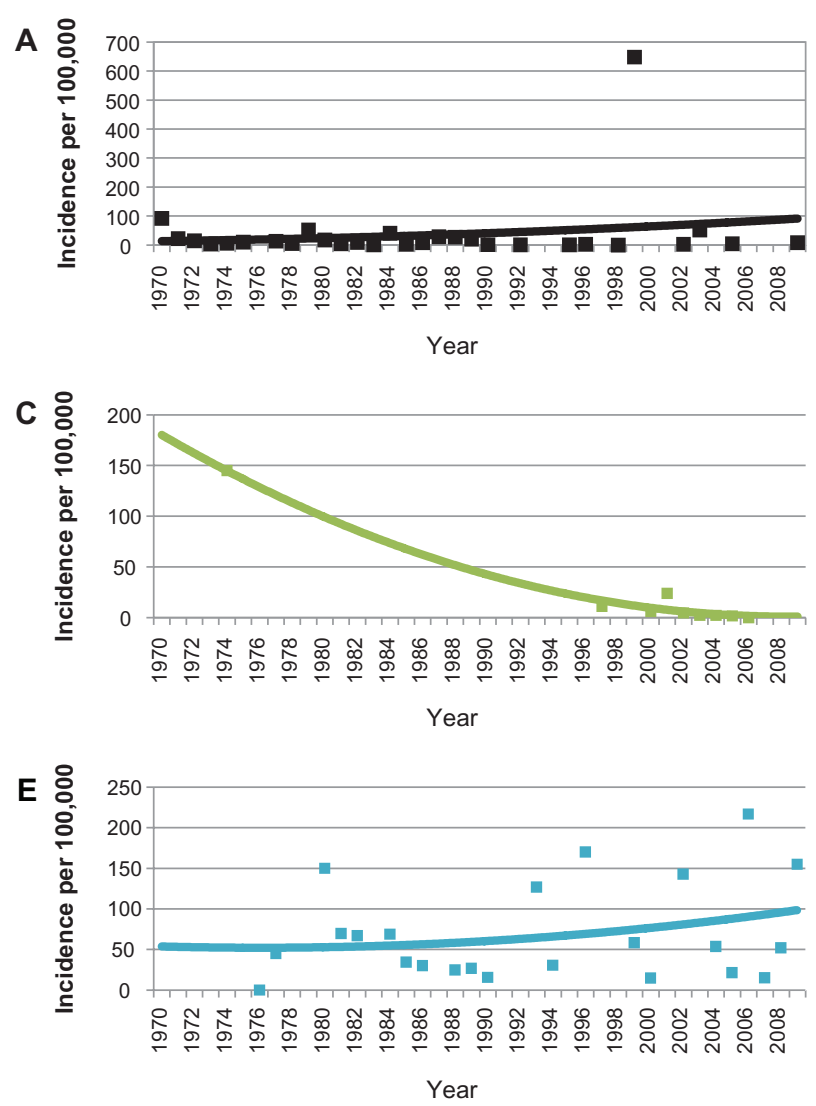
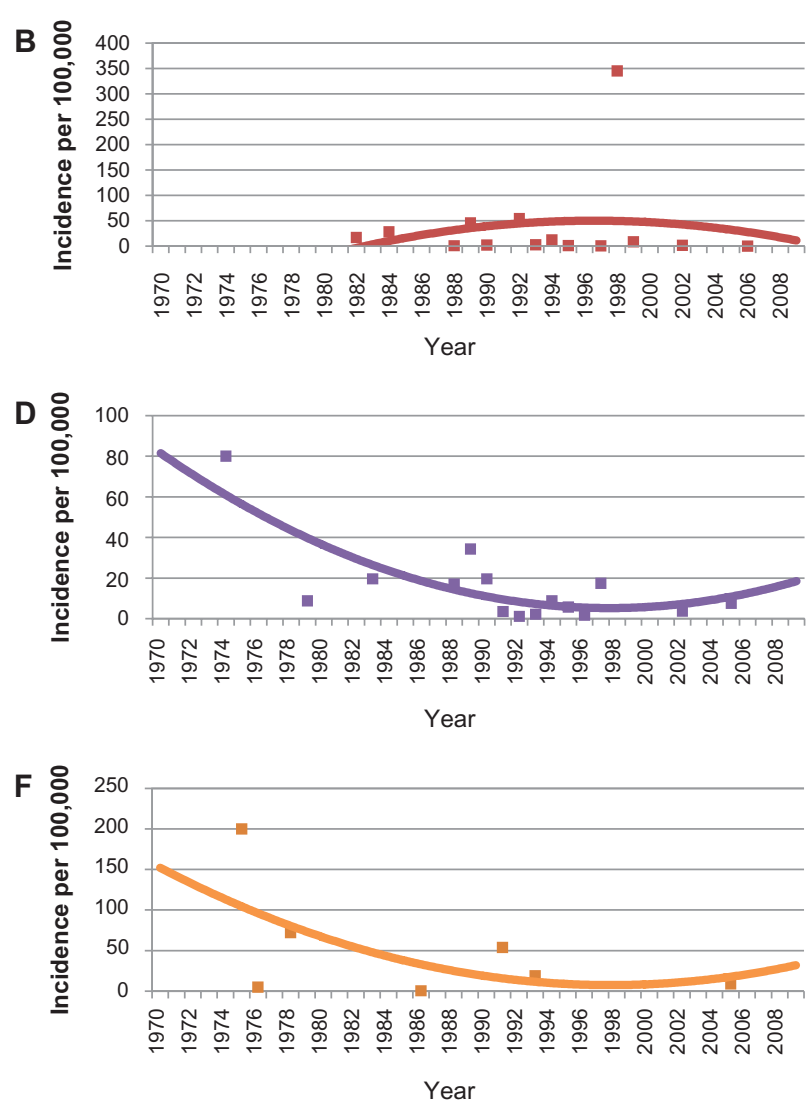

Figure 8 Trends of acute rheumatic fever incidence per 100,000 persons for each WHO region, A) The Americas, B) Europe, C) Africa, D) Eastern Mediterranean, E) Western Pacific, and F) Southeast Asia. Points represent reported incidence from the literature.

Similar practice patterns can be noted in the other poorer WHO regions - Western Pacific and Southeast Asia. Because of the endemic nature of ARF in these regions and the marked impact of progression to chronic RHD, it is reasonable to be aggressive with ARF diagnosis and treatment.

The decrease in ARF incidence is consistent with prior studies that have shown the incidence to be decreasing since the early 20th century. This trend has been attributed to improved living conditions, the use of antibiotics for GABHS pharyngitis and possibly shifting GABHS serotypes. The upward trend in our calculated incidence of ARF in the Americas is likely due to the high incidence reported from Mexico in 1995, which is easily seen as an outlier in the maps in Figures 4 and 6. The apparent increase in incidence in the Western Pacific is more likely improved recognition and reporting of ARF in this region. The reported incidence is only now approaching an average $100 / 100,000$ people, which is likely what the true incidence has been. One possibility for the high incidence of ARF in the Western Pacific region is that many of the countries are small island nations. These countries have small, relatively isolated populations, and so even a small outbreak of ARF can be calculated as a high incidence level, given relatively small denominators. ${ }^{133,161}$

The prevalence of RHD appears to be increasing worldwide. Given that the incidence of ARF has been decreasing in most regions, it is not likely due to increases in the disease. Major advances in medical and surgical treatments for RHD have led to increased survival, which has contributed to an increased prevalence of RHD. RHD is also more rigorously sought out, and newer studies relying on echocardiography to enhance the diagnosis of RHD have shown that subclinical carditis exists at rates up to 10 times higher than that diagnosed by examination alone. ${ }^{2-6}$ Recognition of subclinical carditis will identify those children who would benefit from secondary antibiotic prophylaxis and hopefully prevent the progression to clinically significant RHD. Population-wide echocardiographic screenings may be subject to length time bias or pseudodisease, and the children diagnosed are likely to be among the majority of ARF patients in whom carditis resolves within a year of initial attack. Nevertheless, their increased likelihood 


\section{A}

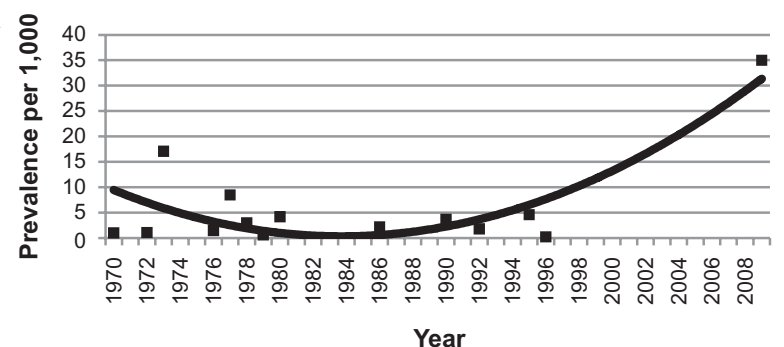

C

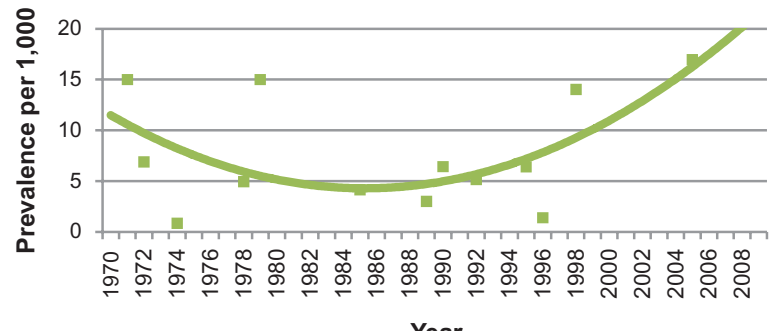

$E$

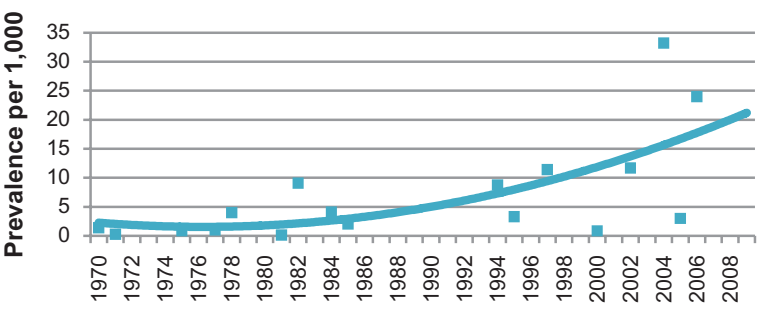

Year
B

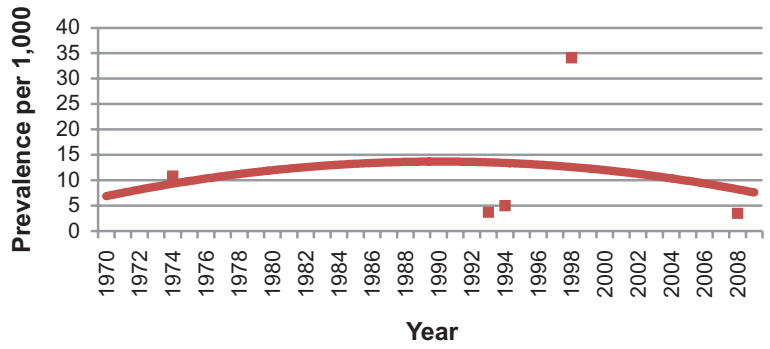

D 8

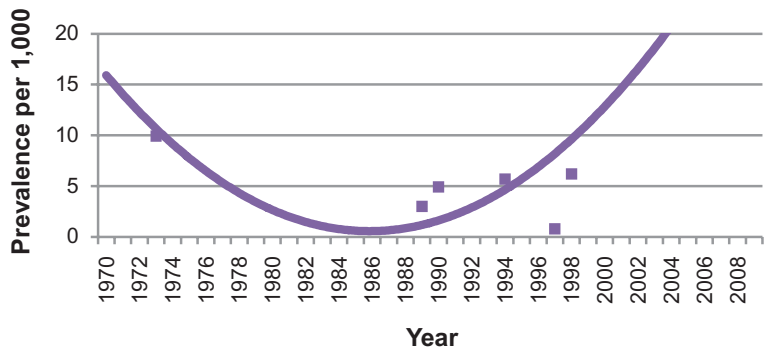

$F$

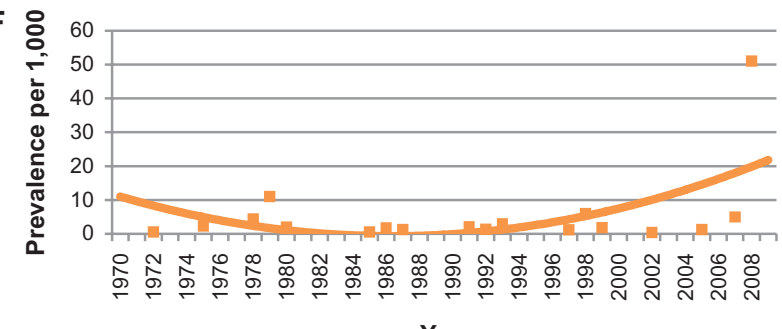

Year

Figure 9 Trends of rheumatic heart disease prevalence per 1000 persons for each WHO region, A) The Americas, B) Europe, C) Africa, D) Eastern Mediterranean, E) Western Pacific, and F) Southeast Asia. Points represent reported prevalence from the literature.

of recurrent ARF, and worsening of prior valvar lesions, makes it appropriate that these children receive secondary antibiotic prophylaxis.

Given the relative ease and low cost of GABHS pharyngitis treatment to prevent ARF occurrence, there is little excuse for hundreds of thousands of new cases of ARF annually. Authors cite varying reasons such as patients not seeking care for pharyngitis, poor compliance with antimicrobial regimens, or even ARF without a clinically apparent preceding sore throat as missed opportunities to prevent ARF. ${ }^{242,243} \mathrm{~A}$ recent meta-analysis of the treatment of GABHS pharyngitis to prevent ARF concluded that there would be an approximately $60 \%$ reduction in cases of ARF if pharyngitis was appropriately treated, especially in endemic areas. ${ }^{243}$ These are similar to Gordis' findings from the 1970 s in Baltimore. ${ }^{242}$ Implementing systematic sur-

Table 6 Percentage of major and minor criteria by WHO region and for all reported studies

\begin{tabular}{|c|c|c|c|c|c|c|c|c|c|c|c|c|}
\hline \multirow[t]{2}{*}{ WHO region } & \multirow[t]{2}{*}{ Males } & \multirow[t]{2}{*}{ Recurrences } & \multicolumn{5}{|c|}{ Major criteria } & \multicolumn{5}{|c|}{ Minor criteria } \\
\hline & & & Carditis & Arthritis & EM & Chorea & Nodules & Arthralgia & Fever & $\uparrow \mathbf{P R}$ & ESR & ASO \\
\hline The Americas & $54.7 \%$ & $22.0 \%$ & $52.8 \%$ & $64.4 \%$ & $7.8 \%$ & $15.3 \%$ & $3.8 \%$ & $40.9 \%$ & $63.9 \%$ & $23.3 \%$ & $84.2 \%$ & $79.4 \%$ \\
\hline Europe & $54.7 \%$ & $7.9 \%$ & $62.0 \%$ & $65.7 \%$ & $5.5 \%$ & $12.3 \%$ & $8.0 \%$ & $43.1 \%$ & $68.9 \%$ & $26.3 \%$ & $81.5 \%$ & $78.3 \%$ \\
\hline Africa & $50.1 \%$ & $17.9 \%$ & $63.3 \%$ & $48.9 \%$ & $1.7 \%$ & $8.8 \%$ & $4.8 \%$ & $55.5 \%$ & $35.4 \%$ & $22.7 \%$ & $52.9 \%$ & $48.7 \%$ \\
\hline Eastern & $54.4 \%$ & $27.9 \%$ & $60.3 \%$ & $63.5 \%$ & $2.8 \%$ & $8.0 \%$ & $1.6 \%$ & $34.5 \%$ & $74.8 \%$ & $20.3 \%$ & $90.5 \%$ & $86.9 \%$ \\
\hline \multicolumn{13}{|l|}{ Mediterranean } \\
\hline Western Pacific & $48.2 \%$ & $22.6 \%$ & $67.5 \%$ & $54.3 \%$ & $11.0 \%$ & $11.7 \%$ & $1.5 \%$ & $35.1 \%$ & $68.4 \%$ & $24.7 \%$ & $91.0 \%$ & $72.3 \%$ \\
\hline Southeast Asia & $57.4 \%$ & $33.9 \%$ & $66.0 \%$ & $46.0 \%$ & $0.8 \%$ & $15.4 \%$ & $4.4 \%$ & $45.5 \%$ & $71.3 \%$ & $28.9 \%$ & $71.9 \%$ & $60.9 \%$ \\
\hline All & $53.7 \%$ & $21.9 \%$ & $59.5 \%$ & $59.3 \%$ & $5.9 \%$ & $12.9 \%$ & $3.7 \%$ & $40.7 \%$ & $65.6 \%$ & $24.1 \%$ & $81.4 \%$ & $75.3 \%$ \\
\hline
\end{tabular}

Note: Proportions are restricted to acute rheumatic fever patients.

Abbreviations: EM, erythema marginatum; $\uparrow$ PR, prolonged PR interval on ECG; ESR, increased erythrocyte sedimentation rate; ASO, elevated antistreptolysin O titer. 


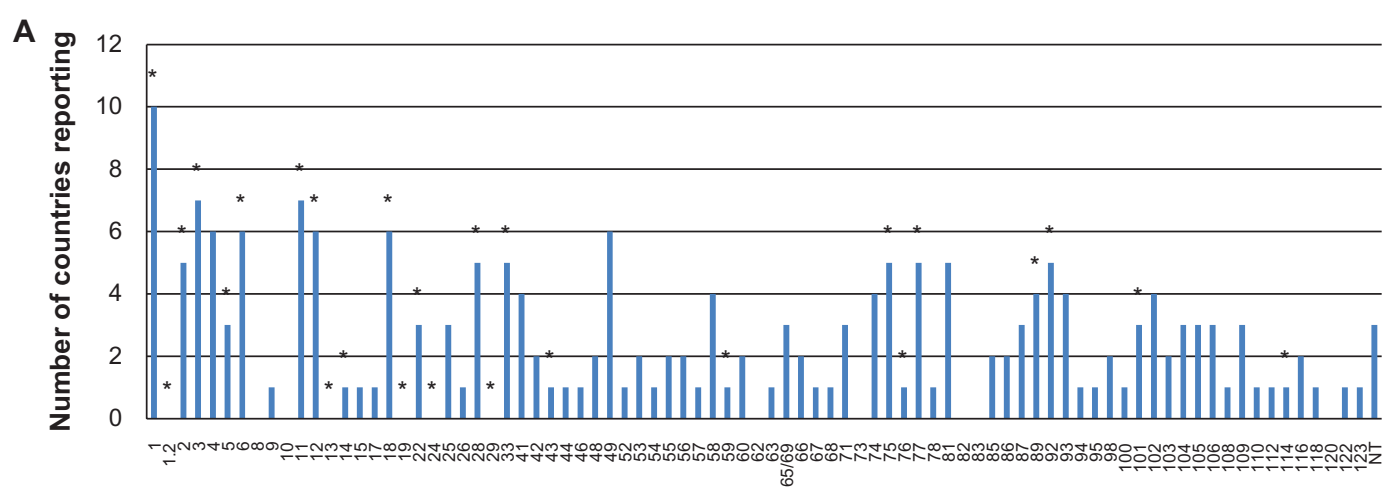

M-type
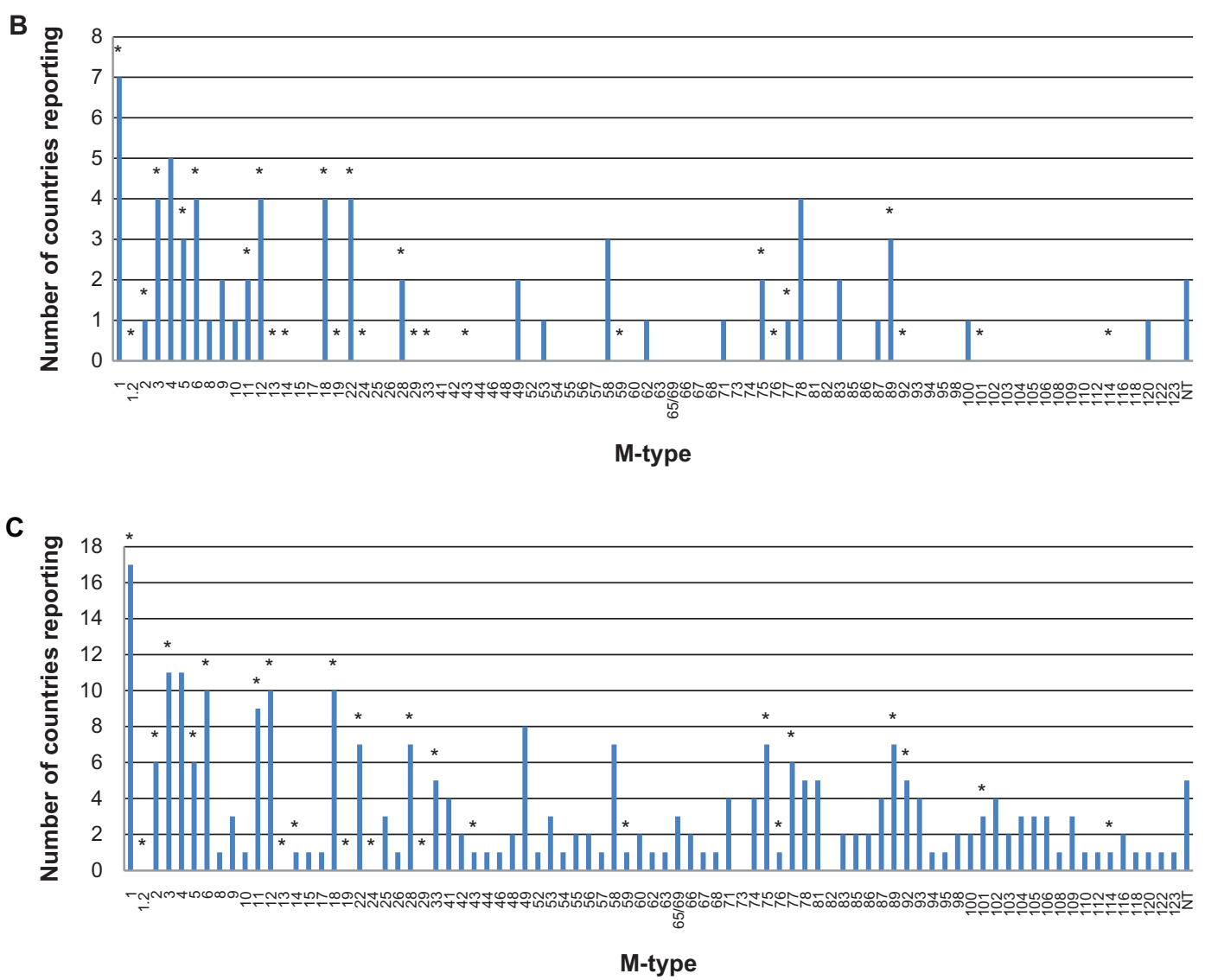

Figure 10 Number of reported occurrences of each streptococcal M-type in A) developing nations, B) developed nations, and C) both combined. Note: *denotes M-types contained in 26-valent GABHS vaccine.

Abbreviation: NT, nontypeable.

veillance and treatment of GABHS pharyngitis, particularly through school-based programs, is crucial to the control and prevention of ARF. ${ }^{244}$ In highly endemic areas, some providers choose to empirically treat patients in the 5 - to 15 -year age range with fever and complaints of sore throat, even without any laboratory evidence of GABHS infection (M.D.S., personal communication). With the low risk of side effects or induction of antibiotic resistance with penicillin therapy compared with the significant risk associated with ARF, this strategy may be justified.
The likelihood of genetic susceptibility to ARF is high, given the increased occurrence of ARF among families and monozygotic twins. ${ }^{28,245}$ The HLA-D8/17 and HLADR7 types are the most represented in the literature among patients with ARF and RHD, but there are still many other HLA alleles that are identified in only single studies. ${ }^{27-45,245}$ The variability in reported HLA alleles associated with ARF and RHD could be due to genetic differences in the populations studied or differences in local streptococcal strains. Given the current state of the literature, it is hard 
to make generalizations about a single "rheumatic" HLA allele, and there are likely multiple HLA alleles that, in combination, increase an individual's susceptibility to ARF and RHD. This is an area that needs continued research efforts to help target ARF prevention strategies to higherrisk populations.

As discussed previously, the availability of a GABHS vaccine would be the best form of ARF prevention, especially since not all patients report upper respiratory infection symptoms or sore throat before their initial ARF occurrence. However, as shown in Figure 10, the M-types present in the 26-valent GABHS vaccine being developed do not represent many of the M-types found in the developing world. Since we do not know all the possible "rheumatogenic" M-types, not vaccinating against prevalent M-types, such as 49, 58, and 81 , may be missing the opportunity to prevent many cases of ARF, especially in developing nations where ARF and RHD are endemic. The vaccines that target the conserved region of the M-protein are likely to provide better protection, but they are all currently in the experimental stage. ${ }^{68}$

Rheumatic fever remains a serious public health problem throughout the world. Despite our major advances in medical technology and understanding, we have not eradicated this disease. While a greater understanding of the detailed mechanisms of disease onset will advance scientific knowledge, it may not matter if one person is more susceptible to developing chorea when exposed to streptococcal M-type 19 or another to developing carditis when exposed to streptococcal M-type 49; in the end, both will develop some form of ARF, and the common denominator is exposure to GABHS. Preventing or providing early treatment for streptococcal infections will be the most important step to worldwide ARF eradication. It is hoped that presenting the continued worldwide problem of ARF and RHD will help promote further study into strategies to reduce the burden of this disease.

\section{Disclosure}

The authors report no conflicts of interest.

\section{References}

1. Carapetis JR, Steer AC, Mulholland EK, Weber M. The global burden of group A streptococcal diseases. Lancet Infect Dis. 2005;5: 685-694.

2. Marijon E, Ou P, Celermajer DS, et al. Prevalence of rheumatic heart disease detected by echocardiographic screening. $N$ Engl J Med. 2007; $357: 470-476$.

3. Carapetis JR, Hardy M, Fakakovikaetau T, et al. Evaluation of a screening protocol using auscultation and portable echocardiography to detect asymptomatic rheumatic heart disease in Tongan schoolchildren. Nat Clin Pract Cardiovasc Med. 2008;5:411-417.
4. Sadiq M, Islam K, Abid R, et al. Prevalence of rheumatic heart disease in school children of urban Lahore. Heart. 2009;95:353-357.

5. Paar JA, Berrios NM, Rose JD, et al. Prevalence of rheumatic heart disease in children and young adults in Nicaragua. Am J Cardiol. 2010; 105:1809-1814.

6. Bhaya M, Panwar S, Beniwal R, Panwar RB. High prevalence of rheumatic heart disease detected by echocardiography in school children. Echocardiography. 2010;27:448-453.

7. Fleming PR. Recognition of rheumatic heart disease. Br Heart J. 1977; 39:1045-1050.

8. Cheadle WB. Harveian lectures on the various manifestations of the rheumatic state as exemplified in childhood and early life. Lancet. 1889; 133:821-827.

9. Poynton FJ, Paine A. The etiology of rheumatic fever. Lancet. 1900; $156: 861-869$.

10. Beattie JM. A contribution to the bacteriology of rheumatic fever. $J$ Exp Med. 1907;9:186-206.

11. Viruses and rheumatic fever. Canad M Ass J. 1935;33:536-538.

12. Li Y, Pan Z, Ji Y, Zhang H, Archard LH. Herpes simplex virus type 1 infection in rheumatic valvar disease. Heart. 2005;91: $87-88$.

13. Olgunturk R, Okur I, Cirak MY, et al. The role of viral agents in aetiopathogenesis of acute rheumatic fever. Clin Rheumatol. 2010. [Epub Apr 19].

14. World Health Organization. WHO programme for the prevention of rheumatic fever/rheumatic heart disease in 16 developing countries: report from Phase I (1986-90). WHO Cardiovascular Diseases Unit and principal investigators. Bull World Health Organ. 1992;70:213-218.

15. Jones TD. Diagnosis of rheumatic fever. JAMA. 1944;126:481-484.

16. Jones criteria (revised) for guidance in the diagnosis of rheumatic fever. Circulation. 1965;32:664-668.

17. Jones criteria (revised) for guidance in the diagnosis of rheumatic fever. Circulation. 1984;69:204A-208A.

18. Special Writing Group of the Committee on Rheumatic Fever, Endocarditis and Kawasaki Disease of the Council on Cardiovascular Disease in the Young of the American Heart Association. Guidelines for the diagnosis of rheumatic fever. Jones Criteria, 1992 Update. JAMA. 1992;268:2069-2073.

19. Ferrieri P for the Jones Criteria Working Group. Proceedings of the Jones Criteria Workshop. Circulation. 2002;106:2521-2523.

20. Ramakrishnan S. Echocardiography in acute rheumatic fever. Ann Pediatr Card. 2009;2:61-64.

21. WHO Expert Consultation on Rheumatic Fever and Rheumatic Heart Disease. Rheumatic fever and rheumatic heart disease: report of a WHO Expert Consultation, Geneva, 29 Oct - 1 Nov 2001. Geneva: WHO, 2004. (WHO Technical Report Series No. 923).

22. Carapetis JR, Brown A, Wilson NJ, Edwards KN. An Australian guideline for rheumatic fever and rheumatic heart disease: an abridged outline. Med J Aust. 2007;186:581-586.

23. Beg A, Sadiq M. Subclinical valvulitis in children with acute rheumatic fever. Pediatr Cardiol. 2008;29:619-623.

24. Veasy LG, Tani LY, Minich L. The logic for extending the use of echocardiography beyond childhood to detect subclinical rheumatic heart disease. Cardiol Young. 2009;19:30-33.

25. Cunningham MW. Pathogenesis of group A streptococcal infections. Clin Microbiol Rev. 2000;13:470-511.

26. Wilson MG, Schweitzer MD. Rheumatic fever as a familial disease. Environment, communicability and heredity in their relation to the observed familial incidence of the disease. J Clin Invest. 1937;16: 555-570.

27. Caughey DE, Douglas R, Wilson W, Hassall IB. HL-A antigens in europeans and maoris with rheumatic fever and rheumatic heart disease. J Rheumatol. 1975;2:319-322.

28. Guilherme L, Ramasawmy R, Kalil J. Rheumatic fever and rheumatic heart disease: genetics and pathogenesis. Scand J Immunol. 2007;66: 199-207.

29. Naito S, Kitajima K, Arakawa K. HLA and rheumatic heart disease in Japanese. Am Heart J. 1983;106(5 Pt 1):1164-1167. 
30. Guilherme L, Kalil J. Rheumatic fever and rheumatic heart disease: cellular mechanisms leading autoimmune reactivity and disease. J Clin Immunol. 2010;30:17-23.

31. Maharaj B, Hammond MG, Appadoo B, Leary WP, Pudifin DJ. HLA-A, $\mathrm{B}, \mathrm{DR}$, and DQ antigens in black patients with severe chronic rheumatic heart disease. Circulation. 1987;76:259-261.

32. Taneja V, Mehra NK, Reddy KS, et al. HLA-DR/DQ antigens and reactivity to $\mathrm{B}$ cell alloantigen $\mathrm{D} 8 / 17$ in Indian patients with rheumatic heart disease. Circulation. 1989;80:335-340.

33. Khanna AK, Buskirk DR, Williams RC Jr, et al. Presence of a non-HLA $B$ cell antigen in rheumatic fever patients and their families as defined by a monoclonal antibody. J Clin Invest. 1989;83:1710-1716.

34. Guilherme L, Weidebach W, Kiss MH, Snitcowsky R, Kalil J. Association of human leukocyte class II antigens with rheumatic fever or rheumatic heart disease in a Brazilian population. Circulation. 1991;83:1995-1998.

35. Ozkan M, Carin M, Sönmez G, Senocak M, Ozdemir M, Yakut C. HLA antigens in Turkish race with rheumatic heart disease. Circulation. 1993;87:1974-1978.

36. Olmez U, Turgay M, Ozenirler S, et al. Association of HLA class I and class II antigens with rheumatic fever in a Turkish population. Scand $J$ Rheumatol. 1993;22:49-52.

37. Maharaj B, Khedun SM, Hammond MG, van der Byl K. HLA-A, B, $\mathrm{DR}$, and DQ antigens in Indian patients with severe chronic rheumatic heart disease. Jpn Heart J. 1997;38:663-668.

38. Visentainer JE, Pereira FC, Dalalio MM, Tsuneto LT, Donadio PR, Moliterno RA. Association of HLA-DR7 with rheumatic fever in the Brazilian population. J Rheumatol. 2000;27:1518-1520.

39. Harel L, Zeharia A, Kodman Y, Straussberg R, Zabriskie JB, Amir J. Presence of the $\mathrm{d} 8 / 17$ B-cell marker in children with rheumatic fever in Israel. Clin Genet. 2002;61:293-298.

40. Stanevicha V, Eglite J, Sochnevs A, Gardovska D, Zavadska D, Shantere R. HLA class II associations with rheumatic heart disease among clinically homogeneous patients in children in Latvia. Arthritis Res Ther. 2003;5:R340-R346.

41. Hernández-Pacheco G, Aguilar-García J, Flores-Domínguez C, et al. MHC class II alleles in Mexican patients with rheumatic heart disease. Int J Cardiol. 2003;92:49-54.

42. Harrington Z, Visvanathan K, Skinner NA, Curtis N, Currie BJ, Carapetis JR. B-cell antigen D8/17 is a marker of rheumatic fever susceptibility in Aboriginal Australians and can be tested in remote settings. Med J Aust. 2006;184:507-510.

43. Stanevicha V, Eglite J, Zavadska D, Sochnevs A, Shantere R, Gardovska D. HLA class II DR and DQ genotypes and haplotypes associated with rheumatic fever among a clinically homogeneous patient population of Latvian children. Arthritis Res Ther. 2007;9:R58.

44. Gündogdu F, Islamoglu Y, Pirim I, et al. Human leukocyte antigen (HLA) class I and II alleles in Turkish patients with rheumatic heart disease. J Heart Valve Dis. 2007;16:293-299.

45. El-Hagrassy N, El-Chennawi F, Zaki Mel-S, Fawzy H, Zaki A, Joseph N. HLA class I and class II HLA DRB profiles in Egyptian children with rheumatic valvular disease. Pediatr Cardiol. 2010;31:650-656.

46. Cavelti PA. Autoantibodies in rheumatic fever. Proc Soc Exp Biol Med. 1945;60:379-381.

47. Cavelti PA. Studies on the pathogenesis of rheumatic fever: I. Experimental production of autoantibodies to heart, skeletal muscle and connective tissue. Arch Pathol (Chic). 1947;44:1-12.

48. Cavelti PA. Studies on the pathogenesis of rheumatic fever: II. Cardiac lesions produced in rats by means of autoantibodies to heart and connective tissues. Arch Pathol (Chic). 1947;44:13-27.

49. Kaplan MH, Meyeserian M. An immunological cross-reaction between group-A streptococcal cells and human heart tissue. Lancet. 1962;279: 706-710.

50. Kaplan MH, Frengley JD. Autoimmunity to the heart in cardiac disease. Current concepts of the relation of autoimmunity to rheumatic fever, postcardiotomyand postinfarction syndromes and cardiomyopathies. Am J Cardiol. 1969;24:459-473.
51. Kaplan EL. Pathogenesis of acute rheumatic fever and rheumatic heart disease: evasive after half a century of clinical, epidemiological, and laboratory investigation. Heart. 2005;91:3-4.

52. Heart apical 2C anatomy. http://upload.wikimedia.org/wikipedia/ commons/f/f9/Heart_apical_2C_anatomy.jpg. By Patrick J. Lynch, medical illustrator (Patrick J. Lynch, medical illustrator)[see page for license], via Wikimedia Commons. Accessed October 28, 2010.

53. Stingl C, Moller JH, Binstadt BA. Cardiac operations for North American children with rheumatic diseases: 1985-2005. Pediatr Cardiol. 2010;31:66-73.

54. Cheunsuchon P, Chuangsuwanich T, Samanthai N, Warnnissorn M, Leksrisakul P, Thongcharoen P. Surgical pathology and etiology of 278 surgically removed mitral valves with pure regurgitation in Thailand. Cardiovasc Pathol. 2007;16:104-110.

55. Nkomo VT. Epidemiology and prevention of valvular heart diseases and infective endocarditis in Africa. Heart. 2007;93:1510-1519.

56. Pazdernik M, Baddour LM, Pelouch R. Infective endocarditis in the Czech Republic: eight years of experience at one of the country's largest medical centers. J Heart Valve Dis. 2009;18:395-400.

57. Sucu M, Davutoğlu V, Ozer O, Aksoy M. Epidemiological, clinical and microbiological profile of infective endocarditis in a tertiary hospital in the South-East Anatolia Region. Turk Kardiyol Dern Ars. 2010;38: 107-111.

58. Colquhoun SM, Carapetis JR, Kado JH, Steer AC. Rheumatic heart disease and its control in the Pacific. Expert Rev Cardiovasc Ther. 2009; 7:1517-1524.

59. Singer HS, Loiselle CR, Lee O, Garvey MA, Grus FH. Anti-basal ganglia antibody abnormalities in Sydenham chorea. J Neuroimmunol. 2003;136:154-161.

60. Kirvan CA, Swedo SE, Heuser JS, Cunningham MW. Mimicry and autoantibody-mediated neuronal cell signaling in Sydenham chorea. Nat Med. 2003;9:914-920.

61. Heye N, Jergas M, Hötzinger H, Farahati J, Pöhlau D, Przuntek H. Sydenham chorea: clinical, EEG, MRI and SPECT findings in the early stage of the disease. J Neurol. 1993;240:121-123.

62. Colony HS, Malamud N. Sydenham's chorea: a clinicopathologic study. Neurology. 1956;6:672-676.

63. Emery ES, Vieco PT. Sydenham Chorea: magnetic resonance imaging reveals permanent basal ganglia injury. Neurology. 1997;48: 531-533.

64. Faustino PC, Terreri MT, da Rocha AJ, Zappitelli MC, Lederman HM, Hilário MO. Clinical, laboratory, psychiatric and magnetic resonance findings in patients with Sydenham chorea. Neuroradiology. 2003;45: 456-462.

65. American Academy of Pediatrics. Group A streptococcal infections. In: Pickering LK, Baker CJ, Kimberlin DW, Long SS, editors. Red Book: 2009 Report of the Committee on Infectious Diseases, 28th ed. Elk Grove Village, IL: American Academy of Pediatrics; 2009: 616-628.

66. Gerber MA, Baltimore RS, Eaton CB, et al. Prevention of rheumatic fever and diagnosis and treatment of acute Streptococcal pharyngitis: a scientific statement from the American Heart Association Rheumatic Fever, Endocarditis, and Kawasaki Disease Committee of the Council on Cardiovascular Disease in the Young, the Interdisciplinary Council on Functional Genomics and Translational Biology, and the Interdisciplinary Council on Quality of Care and Outcomes Research: endorsed by the American Academy of Pediatrics. Circulation. 2009;119: 1541-1551.

67. Olive C. Progress in M-protein-based subunit vaccines to prevent rheumatic fever and rheumatic heart disease. Curr Opin Mol Ther. 2007;9:25-34.

68. Guilherme L, Postol E, Freschi de Barros S, et al. A vaccine against S. pyogenes: design and experimental immune response. Methods. 2009; 49:316-321.

69. Hu MC, Walls MA, Stroop SD, Reddish MA, Beall B, Dale JB. Immunogenicity of a 26-valent group A streptococcal vaccine. Infect Immun. 2002;70:2171-2177. 
70. Massell BF, Michael JG, Amezcua J, Siner M. Secondary and apparent primary antibody responses after group A streptococcal vaccination of 21 children. Appl Microbiol. 1968;16:509-518.

71. Massell BF, Honikman LH, Amezcua J. Rheumatic fever following streptococcal vaccination. Report of three cases. JAMA. 1969;207: 1115-1119.

72. Maclagan T. The treatment of acute rheumatism by salicin. Lancet. 1876;107:342-343.

73. Maclagan T. The treatment of acute rheumatism by salicin. Lancet. 1876;107:383-384.

74. Levy RL, Golden R. The treatment of rheumatic carditis by roentgen irradiation of the heart. Am Heart J. 1928;4:127-144.

75. Schultz MP. Studies of ascorbic acid and rheumatic fever II. Test of prophylactic and therapeutic action of ascorbic acid. J Clin Invest. 1936;15:385-391.

76. Glazebrook AJ, Wrigley F. Clinical trials of succinates and of heparin in rheumatic fever. Br Med J. 1949;2:789-791.

77. Taran LM, Szilagyi N. Oxygen therapy in acute rheumatic carditis in children. Bull NY Acad Med. 1950;26:461-467.

78. Treatment of acute rheumatic fever in children a co-operative clinical trial of A.C.T.H., cortisone, and aspirin. A joint report by the Rheumatic Fever Working Party of the Medical Research Council of Great Britain and the Subcommittee of Principal Investigators of the American Council on Rheumatic Fever and Congenital Heart Disease, American Heart Association. Br Med J. 1955;1:555-574.

79. Albert DA, Harel L, Karrison T. The treatment of rheumatic carditis: a review and meta-analysis. Medicine (Baltimore). 1995;74: $1-12$.

80. Uziel Y, Hashkes PJ, Kassem E, Padeh S, Goldman R, Wolach B. The use of naproxen in the treatment of children with rheumatic fever. J Pediatr. 2000;137:269-271.

81. Hashkes PJ, Tauber T, Somekh E, et al for the Pediatric Rheumatlogy Study Group of Israel. Naproxen as an alternative to aspirin for the treatment of arthritis of rheumatic fever: a randomized trial. J Pediatr. 2003;143:399-401.

82. Paz JA, Silva CA, Marques-Dias MJ. Randomized double-blind study with prednisone in Sydenham's chorea. Pediatr Neurol. 2006;34: 264-269.

83. Pelajo CF, Lopez-Benitez JM, Torres JM, de Oliveira SK. Adherence to secondary prophylaxis and disease recurrence in 536 Brazilian children with rheumatic fever. Pediatr Rheumatol Online J. 2010;8:22.

84. Lue HC, Wu MH, Wang JK, Wu FF, Wu YN. Three- versus four-week administration of benzathine penicillin G: effects on incidence of streptococcal infections and recurrences of rheumatic fever. Pediatrics. 1996;97(6 Pt 2):984-988.

85. Sievers J, Hall P. Incidence of acute rheumatic fever. Br Heart J. 1971;33:833-836.

86. Annegers JF, Pillman NL, Weidman WH, et al. Rheumatic fever in Rochester, Minnesota, 1935-1978. Mayo Clin Proc. 1982;57:753-757.

87. Leff S. Modern trends in acute rheumatism. Ann Rheum Dis. 1956; 15:33-39.

88. Morton WE, Lichty JA. Rheumatic heart disease epidemiology. II. Colorado's high-risk low-socioeconomic region in 1960. Am J Epidemiol. 1970;92:113-120.

89. Arguedas A, Mohs E. Prevention of rheumatic fever in Costa Rica. J Pediatr. 1992;121:569-572.

90. Community control of rheumatic heart disease in developing countries: 1 A major public health problem. WHO Chron. 1980;34:336-345.

91. De Silva S. Incidence of rheumatic fever in Ceylon. Arch Dis Child. 1959;34:247-249.

92. Gordis L, Lilienfeld A, Rodriguez R. Studies in the epidemiology and preventability of rheumatic fever - I. Demographic factors and the incidence of acute attacks. J Chronic Dis. 1969;21: 645-654.

93. Veasy LG, Wiedmeier SE, Orsmond GS, et al. Resurgence of acute rheumatic fever in the intermountain area of the United States. NEngl J Med. 1987;316:421-427.
94. Brownell KD, Bailen-Rose F. Acute rheumatic fever in children. Incidence in a borough of New York City. JAMA. 1973;224: 1593-1597.

95. Quinn RW, Federspiel CF. The incidence of rheumatic fever in metropolitan Nashville, 1963-1969. Am J Epidemiol. 1974;99: 273-280.

96. Negus RM. Rheumatic fever in Western Fiji: the female preponderence. Med J Aust. 1971;2:251-254.

97. Phibbs B, Lundin SR, Watson WB, Corbett JJ. Experience of a Wyoming County streptococcal control project. West J Med. 1988;148: 546-550.

98. Kawakita S. Rheumatic fever and rheumatic heart disease in Japan. Jpn Circ J. 1986;50:1241-1245.

99. Rheumatic fever in the U.S.S.R. Can Med Assoc J. 1961;84:856.

100. Abbasi AS, Hashmi JA, Robinson RD Jr, Suraya S, Ali Syed S. Prevalence of heart disease in school children of Karachi. Am J Cardiol. 1966;18:544-547.

101. Berry JN. Prevalence survey for chronic rheumatic heart disease and rheumatic fever in northern India. Br Heart J. 1972;34: 143-149.

102. Lue HC, Wu MH, Hwang BT, et al. Establishment of a rheumatic heart disease registry in Taipei: an early appraisal. NZ Med J. 1988; 101(847 Pt 2):410-411.

103. Rheumatic fever and rheumatic heart disease. Report of a WHO Study Group. World Health Organization. 1988 (Technical Report Series No. 764):5-58.

104. Hassell TA, Renwick S, Stuart KL. Rheumatic fever and rheumatic heart disease in Barbados: detection and prophylaxis. Br Med J. 1972; 3:387-389

105. Noah PK. Trends in acute rheumatic fever. The Barbados experience. J Trop Pediatr. 1994;40:94-96.

106. Longstaffe S, Postl B, Kao H, Nicolle L, Ferguson CA. Rheumatic fever in native children in Manitoba. Can Med Assoc J. 1982;127: 497-498.

107. Hutten-Czapski P. Acute rheumatic fever - no epidemic in Ontario. Can J Public Health. 1989;80:71-72.

108. Luque C, Cisternas FA, Araya M. Changes in the patterns of disease after the epidemiological transition in health in Chile, 1950-2003. Rev Med Chil. 2006;134:703-712.

109. Berríos X, del Campo E, Wilson C, Blásquez J, Morales A, Quesney F. Acute rheumatic fever in the southeastern metropolitan area of Santiago, Chile, 1976-1981. Bull Pan Am Health Organ. 1984;18: 389-396.

110. Arguedas A, Mohs E. Prevention of rheumatic fever in Costa Rica. J Pediatr. 1992;121:569-572.

111. Nordet P, Lopez R, Dueñas A, Sarmiento L. Prevention and control of rheumatic fever and rheumatic heart disease: the Cuban experience (1986-1996-2002). Cardiovasc J Afr. 2008;19:135-140.

112. Neutze JM. Rheumatic fever and rheumatic heart disease in the western Pacific region. N Z Med J. 1988;101(847 Pt 2):404- 406.

113. Bach JF, Chalons S, Forier E, et al. 10-year educational programme aimed at rheumatic fever in two French Caribbean islands. Lancet. 1996;347:644-648.

114. Alto W, Rikin T, Falanruw L, et al. Rheumatic fever in Micronesia. Pac Health Dialog. 1994;1:13-18.

115. Giannoulia-Karantana A, Anagnostopoulos G, Kostaridou S, Georgakopoulou T, Papadopoulou A, Papadopoulos G. Childhood acute rheumatic fever in Greece: experience of the past 18 years. Acta Paediatr. 2001;90:809-812.

116. Chin WA. Rheumatic fever and rheumatic heart disease in children in Guyana. West Indian Med J. 1979;28:228-234.

117. Koshi G, Benjamin V. Surveillance of streptococcal infections in children in a south Indian community - a pilot survey. Indian J Med Res. 1977;66:379-388.

118. Koshi G, Benjamin V, Cherian G. Rheumatic fever and rheumatic heart disease in rural South Indian children. Bull World Health Organ. 1981;59:599-603. 
119. Gharagozloo RA, Daneshpajooh M, Ghavamian P. Rheumatic fever and rheumatic heart disease among 56,8000 inhabitants in southeast Teheran from 1972-1974. Acta Trop. 1976;33:215-222.

120. Habib GS, Saliba WR, Mader R. Rheumatic fever in the Nazareth area during the last decade. Isr Med Assoc J. 2000;2:433-437.

121. Mori C, Okuda R, Nishioka K, Ueda C, Phornphvtkul C. Rheumatic heart disease in childhood: comparative study between Japan and Thailand. Jpn Circ J. 1979;43:487-489.

122. Omar A. Pattern of acute rheumatic fever in a local teaching hospital. Med J Malaysia. 1995;50:125-130.

123. Majeed HA, Yousof AM, Khuffash FA, Yusuf AR, Farwana S, Khan N. The natural history of acute rheumatic fever in Kuwait: a prospective six year follow-up report. J Chronic Dis. 1986;39: 361-369.

124. Majeed HA, Khuffash FA, Sharda DC, Farwana SS, el-Sherbiny AF, Ghafour SY. Children with acute rheumatic fever and acute poststreptococcal glomerulonephritis and their families in a subtropical zone: a three-year prospective comparative epidemiological study. Int J Epidemiol. 1987;16:561-568.

125. Majeed HA, Doudin K, Lubani M, Shaltout A, Doussary L, Suliman MA. Acute rheumatic fever in Kuwait: the declining incidence. Ann Saudi Med. 1993;13:56-59.

126. Kopecká B, Kopecký A. Rheumatic fever in a developing country in North Africa. Cesk Pediatr. 1989;44:533-535.

127. Lennon D, Martin D, Wong E, Taylor LR. Longitudinal study of poststreptococcal disease in Auckland: rheumatic fever, glomerulonephritis, epidemiology and M typing 1981-86. N Z Med J. 1988; 101(847 Pt 2):396-398.

128. Talbot RG. Rheumatic fever and rheumatic heart disease in the Hamilton health district: I. An epidemiological survey. NZ Med J. 1984;97:630-634.

129. Talbot RG. Rheumatic fever in the Hamilton health district: a nine year prospective study. NZ Med J. 1988;101(847 Pt 2):406-408.

130. Flight RJ. The Northland rheumatic fever register. NZ Med J. 1984; 97:671-673.

131. Purchas SH, Wabitsch KR, Taikato MR, Miles M. Rheumatic fever and rheumatic heart disease at the Rotorua Hospital 1971-1982. NZ Med J. 1984;97:675-678.

132. Ogunbi O, Fadahunsi HO, Ahmed I, et al. An epidemiological study of rheumatic fever and rheumatic heart disease in Lagos. J Epidemiol Community Health. 1978;32:68-71.

133. Seckeler MD, Barton LL, Brownstein R. The persistent challenge of rheumatic fever in the Northern Mariana Islands. Int J Infect Dis. 2010;14:e226-e229.

134. Cortina Greus P, Alfonso Sánchez JL, Cortés Vizcaíno C, Smeyers Durá P, González Arraez JI. Epidemiological course of rheumatic fever and rheumatic heart disease in Spain (1951-1986). Rev Sanid Hig Publica (Madr). 1991;65:17-24.

135. Vongprateep C, Dharmasakti D, Sindhavanonda K. The national programme and the control of rheumatic fever and rheumatic heart disease in two project areas of Thailand. NZ Med J. 1988;101(847 Pt 2): 408-410.

136. Finau SA, Taylor L. Rheumatic heart disease and school screening: initiatives at an isolated hospital in Tonga. Med J Aust. 1988;148: 563-567.

137. Earle DP, Potter EV, Poon-King T, et al. Streptococcal infections, acute nephritis and rheumatic fever in Trinidad - further observations. Trans Am Clin Climatol Assoc. 1976;87:224-234.

138. Kechrid A, Kharrat H, Bousnina S, Kriz P, Kaplan EL. Acute rheumatic fever in Tunisia. Serotypes of group A streptococci associated with rheumatic fever. Adv Exp Med Biol. 1997;418:121-123.

139. Karademir S, Demirçeken F, Atalay S, Demircin G, Sipahi T, Teziç T. Acute rheumatic fever in children in the Ankara area in 1990-1992 and comparison with a previous study in 1980-1989. Acta Paediatr. 1994;83:862-865.

140. Hefelfinger DC. Resurgence of acute rheumatic fever in west Alabama. South Med J. 1992;85:261-265.
141. Wallace MR, Garst PD, Papadimos TJ, Oldfield EC 3rd. The return of acute rheumatic fever in young adults. JAMA. 1989;262: 2557-2261.

142. Odio A. The incidence of acute rheumatic fever in a suburban area of Los Angeles - a ten-year study. West J Med. 1986;144:179-184.

143. Ferguson GW, Shultz JM, Bisno AL. Epidemiology of acute rheumatic fever in a multiethnic, multiracial urban community: the Miami-Dade County experience. J Infect Dis. 1991;164:720-725.

144. Chun LT, Reddy V, Rhoads GG. Occurrence and prevention of rheumatic fever among ethnic groups of Hawaii. Am J Dis Child. 1984; 138:476-478.

145. Chun LT, Reddy DV, Yamamoto LG. Rheumatic fever in children and adolescents in Hawaii. Pediatrics. 1987;79:549-552.

146. Chun LT, Reddy DV, Yim GK, Yamamoto LG. Acute rheumatic fever in Hawaii: 1966 to 1988. Hawaii Med J. 1992;51:206-211.

147. Powell KE, Watson DG. Acute rheumatic fever in Mississippi: a survey of hospitalized cases, 1964 to 1973. South Med J. 1981;74: $553-557$.

148. Coulehan J, Grant S, Reisinder K, et al. Acute rheumatic fever and rheumatic heart disease on the Navajo reservation, 1962-77. Public Health Rep. 1980;95:62-68.

149. Congeni B, Rizzo C, Congeni J, Sreenivasan VV. Outbreak of acute rheumatic fever in northeast Ohio. J Pediatr. 1987;111;176-179.

150. Hosier DM, Craenen JM, Teske DW, Wheller JJ. Resurgence of acute rheumatic fever. AJDC. 1987;141:730-733.

151. Holmberg SD, Faich GA. Streptococcal pharyngitis and acute rheumatic fever in Rhode Island. JAMA. 1983;290:2307-2312.

152. Leggiadro RJ, Birnbaum SE, Chase NA, Myers LK. A resurgence of acute rheumatic fever in a Mid-South children's hospital. S Med J. 1990;83:1418-1420.

153. Schwartz RH, Hepner SI, Mohsen Z. Incidence of acute rheumatic fever: a suburban community hospital experience during the 1970s. Clin Pediatr (Phila). 1983;22:798-801.

154. Eckerd JM, McJunkin JE. Recent increase in incidence of acute rheumatic fever in southern West Virginia. WV Med J. 1989;85:323-325.

155. Mason T, Fisher M, Kujala G. Acute rheumatic fever in West Virginia. Arch Intern Med. 1991;151:133-136.

156. Carapetis JR, McDonald M, Wilson NJ. Acute rheumatic fever. Lancet. 2005;366:155-168.

157. Ministère de la santé, de la population et de la réforme hospitalière. Situation épidémiologique du rhumatisme articulaire aigu en Algérie 2004. http://www.sante.dz/insp/raa-sommaire.htm. Accessed August 20, 2010.

158. Ministère de la santé, de la population et de la réforme hospitalière. Situation épidémiologique du rhumatisme articulaire aigu en Algérie 2005. http://www.sante.dz/insp/raa-sommaire.htm. Accessed August 20, 2010.

159. Erdem G, Dodd A, Tuua A, et al. Acute rheumatic fever in American Samoa. Pediatr Infect Dis J. 2007;26:1158-1159.

160. Carapetis JR, Wolff DR, Currie BJ. Acute rheumatic fever and rheumatic heart disease in the top end of Australia's Northern Territory. Med J Aust. 1996;164:146-149.

161. Carapetis JR, Currie BJ, Mathews JD. Cumulative incidence of rheumatic fever in an endemic region: a guide to the susceptibility of the population? Epidemiol Infect. 2000;124:239-244.

162. Cann MP, Sive AA, Norton RE, McBride WJ, Ketheesan N. Clinical presentation of rheumatic fever in an endemic area. Arch Dis Child. 2010;95:455-457.

163. Hanna JN, Clark MF. Acute rheumatic fever in Indigenous people in North Queensland: some good news at last? Med J Aust. 2010;192: 581-584.

164. Singwe-Ngandeu M, Meli J, Ntsiba H, et al. Rheumatic diseases in patients attending a clinic at a referral hospital in Yaounde, Cameroon. East Afr Med J. 2007;84:404-409.

165. Carceller A, Tapiero B, Rubin E, Miró J. Acute rheumatic fever: 27 year experience from the Montreal's pediatric tertiary care centers. $A n$ Pediatr (Barc). 2007;67:5-10. 
166. Madden S, Kelly L. Update on acute rheumatic fever: it still exists in remote communities. Can Fam Phys. 2009;55:475-478.

167. Huang ZD, Rao XX, Cen YC, et al. An updated epidemiologic survey of acute rheumatic fever among school-age children in China. Chin J Cardiol. 1998;26:94-97.

168. Chen X, Zhang M, Huang D, et al. An epidemiologic investigation of acute rheumatic fever and rheumatic heart disease among students aged 5-18 in west area of Sichuan Province. Sichuan Da Xие Хие Bao Yi Xue Ban. 2003;34:533-535.

169. Cuboni HD, Finau SA, Cuboni G. Rheumatic fever and rheumatic heart diseases in Fiji: a review from the surveillance system (1996-2000). Pac Health Dialog. 2006;13:39-47.

170. Parks T, Kado J, Colquhoun S, Carapetis J, Steer A. Underdiagnosis of acute rheumatic fever in primary care settings in a developing country Trop Med Int Health. 2009;14:1407-1413.

171. Steer AC, Kado J, Jenney AW, et al. Acute rheumatic fever and rheumatic heart disease in Fiji: prospective surveillance, 2005-2007. Med J Aust. 2009;190:133-135.

172. Olivier C, Portier H, Cohen R, Schlemmer B, Boucot I, Peyramond D. Rhumatisme articulaire aigu: résultats d'une enquête nationale (1995-1997). Bull Épi Hebdom. 1999;12:1-5.

173. Von Koskull S, Truckenbrodt H, Holle R, Hörmann A. Incidence and prevalence of juvenile arthritis in an urban population of southern Germany: a prospective study. Ann Rheum Dis. 2001;60: 940-945.

174. Kafetzis DA, Chantzi FM, Grigoriadou G, Vougiouka O, Liapi G. Incidence and clinical profile of acute rheumatic fever in Greece. Eur J Clin Microbiol Infect Dis. 2005;24:68-70.

175. Ayoub EM, Nelson B, Shulman ST, et al. Group A streptococcal antibodies in subjects with or without rheumatic fever in areas with high or low incidences of rheumatic fever. Clin Diagn Lab Immunol. 2003;10:886-890.

176. Grover A, Dhawan A, Iyengar SD, Anand IS, Wahi PL, Ganguly NK. Epidemiology of rheumatic fever and rheumatic heart disease in a rural community in northern India. Bull World Health Organ. 1993; 71:59-66.

177. Thakur JS, Negi PC, Ahluwalia SK, Vaidya NK. Epidemiological survey of rheumatic heart disease among school children in the Shimla Hills of northern India: prevalence and risk factors. $J$ Epidemiol Community Health. 1996;50:62-67.

178. Vinker S, Zohar E, Hoffman R, Elhayany A. Incidence and clinical manifestations of rheumatic fever: a 6 year community-based survey. Isr Med Assoc J. 2010;12:78-81.

179. Khriesat I, Najada A, Al-Hakim F, Abu-Haweleh A. Acute rheumatic fever in Jordanian children. East Mediterr Health J. 2003;9: 981-987.

180. Jeong EY, Jun BJ, Kim NS, Yum MG, Seo IJ. A study of clinical manifestations of acute rheumatic fever. $J$ Korean Pediatr Cardiol Soc. 2007;11:116-123.

181. Kohler LA, Alik T, Kaplan EL, Anderson FL. A pilot study for the primary prevention of rheumatic fever in Kosrae, Federated States of Micronesia. Pac Health Dialog. 2010;16: 99-108.

182. Bitar FF, Hayek P, Obeid M, Gharzeddine W, Mikati M, Dbaibo GS. Rheumatic fever in children: a 15-year experience in a developing country. Pediatr Cardiol. 2000;21:119-122.

183. Soto López ME, Cordera González de Cosío F, Estrada L, Guel L, Abud Mendoza C, Reyes PA. Rheumatic fever in the 5-year period of 1994-1999 at 2 hospitals in San Luis Potosi and Mexico D.F. Arch Cardiol Mex. 2001;71:127-135.

184. Rayamajhi A, Sharma D, Shakya U. Clinical, laboratory and echocardiographic profile of acute rheumatic fever in Nepali children. Ann Trop Paediatr. 2007;27:169-177.

185. Le Hello S, Doloy A, Baumann F, et al. Clinical and microbial characteristics of invasive Streptococcus pyogenes disease in New Caledonia, a region in Oceania with a high incidence of acute rheumatic fever. J Clin Microbiol. 2010;48:526-530.
186. Jaine R, Baker M, Venugopal K. Epidemiology of acute rheumatic fever in New Zealand 1996-2005. J Paediatr Child Health. 2008; 44:564-571.

187. Atatoa-Carr P, Bell A, Lennon DR. Acute rheumatic fever in the Waikato District Health Board region of New Zealand: 1998-2004. NZ Med J. 2008;121:96-105.

188. Sani MU, Karaye KM, Borodo MM. Prevalence and pattern of rheumatic heart disease in the Nigerian savannah: an echocardiographic study. Cardiovasc J Afr. 2007;18:295-299.

189. Hasab AA, Jaffer A, Riyami AM. Rheumatic heart disease among Omani schoolchildren. East Med Health J. 1997;3:17-23.

190. Eltohami EA, Hajar HA, Folger GM Jr. Acute rheumatic fever in an Arabian Gulf country - effect of climate, advantageous socioeconomic conditions, and access to medical care. Angiology. 1997;48: 481-489.

191. Folomeeva OM, Benevolenskaia LI. Rheumatism in the Russian Federation: statistic and reality. Vestn Ross Akad Med Nauk. 1996;11: 21-24.

192. Viali S. Rheumatic fever and rheumatic heart disease in Samoa. Pac Health Dialog. 2006;13:31-38.

193. Ben Meriem C, Hammami S, Ghédira L, et al. Rhumatisme articulaire aigu chez l'enfant: à propos de 169 cas. J Pédia Puér. 2008; 21:86-92.

194. Ranin L, Opavski N, Djukic S, Mijac V. Epidemiology of diseases caused by Streptococcus pyogenes in Serbia during a nine-year period (1991-1999). Indian J Med Res. 2004; Suppl 119:155-159.

195. Quirós AB. Fiebre reumática. In: MH Rodríguez, editor. Pediatriá, 2nd ed. Ediciones Díaz de Santos; 1994:1159-1166.

196. Bolz D, Tyndall A. Rhumatisme articulaire aigu- encore actuel en Suisse? Forum Médical Suisse. 2006;6:642-646.

197. Karaaslan S, Oran B, Reisli I, Erkul I. Acute rheumatic fever in Konya, Turkey. Pediatr Int. 2000;42:71-75.

198. Ozer S, Hallioğlu O, Ozkutlu S, Celiker A, Alehan D, Karagöz T. Childhood acute rheumatic fever in Ankara, Turkey. Turk J Pediatr. 2005;47:120-124.

199. Hoffman TM, Rhodes LA, Pyles LA, Balian AA, Neal WA, Einzig S. Childhood acute rheumatic fever: a comparison of recent resurgence areas to cases in West Virginia. WV Med J. 1997;93:260-263.

200. Minh Hoa TT, Darmawan J, Chen SL, Van Hung N, Thi Nhi C, Ngoc An T. Prevalence of the rheumatic diseases in urban Vietnam: a WHO-ILAR COPCORD study. J Rheumatol. 2003;30:2252-2256.

201. Strasser T, Rotta J. The control of rheumatic fever and rheumatic heart disease: an outline of WHO activities. WHO Chron. 1973;27: $49-54$.

202. Joint WHO/ISFC meeting on rheumatic fever/rheumatic heart disease control with emphasis on primary prevention, Geneva, 7-9 September 1994. World Health Organ. 1994 (WHO/CVD 94.1):1-52.

203. Silva MO, Bertolami V, Finatti AA, Jatene AD. Estudo da prevalência da febre reumática. Rev Saude Publica. 1979;13:1-6.

204. Bertrand E, Coly M, Chauvet J, et al. Etude de la prévalence des cardiopathies, notamment rhumatismales, en milieu scolaire en Côte d'Ivoire. Bull World Health Organ. 1979;57:471-474.

205. Hallorímsson J. Chronic rheumatic valvular heart disease. An autopsy study. Acta Pathol Microbiol Scand A. 1975;83:633-638.

206. Shrestha NK, Padmavati S. Prevalence of rheumatic heart disease in Delhi school children. Indian J Med Res. 1979;69:821-833.

207. Vijaykumar M, Narula J, Reddy KS, Kaplan EL. Incidence of rheumatic fever and prevalence of rheumatic heart disease in India. Int J Cardiol. 1994;43:221-228.

208. Lue H-C, Chen C-L, Wei H, et al. The natural history of rheumatic fever and rheumatic heart disease in the Orient. Jpn Heart J. 1979;20: 237-252.

209. Naim M, Tjipta GD, Siregar AA, Halim S. Rheumatic fever and rheumatic heart disease at the Department of Child Health, School of Medicine, University of North Sumatera/Dr. Pirngadi Hospital, Medan (1983-1985). Paediatr Indones. 1989;29: 64-71. 
210. Anabwani GM, Amoa AB, Muita AK. Epidemiology of rheumatic heart disease among primary school children in western Kenya. Int $J$ Cardiol. 1989;23:249-252.

211. Jaiyesimi F, Antia AU. Childhood rheumatic heart disease in Nigeria. Trop Geogr Med. 1981;33:8-13.

212. Okoroma EO, Ihenacho IN, Anyanwu CH. Rheumatic fever in Nigerian children. A prospective study of 66 patients. Am J Dis Child. 1981;135: 236-238.

213. Al-Sekait MA, al-Sweliem AA, Tahir M. Rheumatic heart disease in school children in Western District, Saudi Arabia. J R Soc Health. 1990;110:15-16

214. McLaren MJ, Hawkins DM, Koornhof HJ, et al. Epidemiology of rheumatic heart disease in black shcoolchildren of Soweto, Johannesburg. Br Med J. 1975;3:474-478.

215. Ibrahim-Khalil S, Elhag M, Ali E, et al. An epidemiological survey of rheumatic fever and rheumatic heart disease in Sahafa Town, Sudan. J Epidemiol Community Health. 1992;46:477-479.

216. Finau SA, Taylor L. Rheumatic heart disease and school screening: initiatives at an isolated hospital in Tonga. Med J Aust 1988;148: 563-567.

217. Carapetis JR, Currie BJ, Mathews JD. Cumulative incidence of rheumatic fever in an endemic region: a guide to the susceptibility of the population? Epidemiol Infect. 2000;124:239-244.

218. Ahmed J, Mostafa Zaman M, Monzur Hassan MM. Prevalence of rheumatic fever and rheumatic heart disease in rural Bangladesh. Trop Doct. 2005;35:160-161.

219. Meira ZMA, de Castilho SRT, Barros MVL, et al. Prevalence of rheumatic fever in children from a public high school in Belo Horizonte, Brazil. Arch Brasilian Cardiol. 1995;65:331-334.

220. Rao XX, Huang ZD, Cen YC, et al. Current status of rheumatic heart disease in China. Chin J Cardiol. 1998;26:98-100.

221. Zhimin W, Yubao Z, Lei S, et al. Prevalence of chronic rheumatic heart disease in Chinese adults. Int J Cardiol. 2006;107:356-359.

222. Longo-Mbenza B, Bayekula M, Ngiyulu R, et al. Survey of rheumatic heart disease in schoolchildren of Kinshasa town. Int $J$ Cardiol. 1998;63:287-294.

223. Moyen G, Okoko A, Mbika Cardorelle A, et al. Rhumatisme articulaire aigu et cardiopathies rhumatismales de l'enfant a Brazzaville. Médecine d'Afrique Noire. 1999;46:258-263.

224. Kimbally-Kaky G, Gombet T, Voumbo Y, et al. Les Cardiopathies rhumatismales en milieu scolaire à Brazzaville. Med Trop. 2008;68: 603-605.

225. Abdel-Moula AM, Sherif AA, Sallam SA, Mandil AM, Kassem AS, Zaher SR. Prevalence of rheumatic heart disease among school children in Alexandria, Egypt: a prospective epidemiological study. J Egypt Public Health Assoc. 1998;73:233-254.

226. Oli K, Tekle-Haimanot R, Forsgren L, Ekstedt J. Rheumatic heart disease prevalence among schoolchildren of an Ethiopian rural town. Cardiology. 1992;80:152-155.

227. Oli K, Porteous J. Prevalence of rheumatic heart disease among school children in Addis Ababa. East Afr Med J. 1999;76:601-605.
228. Singh PI, Carapetis JR, Buadromo EM, Samberkar PN, Steer AC. The high burden of rheumatic heart disease found on autopsy in Fiji. Cardiol Young. 2008;18:62-69.

229. Kumar R, Raizada A, Aggarwal AK, Ganguly NK. A community-based rheumatic fever/rheumatic heart disease cohort: twelve-year experience. Indian Heart J. 2002;54:54-58.

230. Gupta I, Gupta ML, Parihar A, Gupta CD. Epidemiology of rheumatic and congenital heart diseases in school children. J Indian Med Assoc. 1992;90:57-59.

231. Omurzakova NA, Yamao Y, Saatova GM, et al. High incidence of rheumatic fever and rheumatic heart disease in the republics of Central Asia. Int J Rheum Dis. 2009;12:79-83.

232. Raobijaona H, Andrianjanaka JC, Rakotorimanana DR. Le rhumatisme articulaire aigu (RAA) a antananarivo (Madagascar). Médecine d'Afrique Noire. 1998;45:686-689.

233. Soliman EZ, Juma H. Cardiac disease patterns in northern Malawi: epidemiologic transition perspective. J Epidemiol. 2008;18:204-208.

234. Regmi PR, Pandey MR. Rheumatic fever and rheumatic heart disease in school children of Kathmandu city. Indian Heart J. 1997;49: $518-520$.

235. Ramachandran U, Alurkar V, Thaplia A. Pattern of cardiac diseases in children in Pokhara, Nepal. Kathmandu Univ Med J. 2006;4: 222-227.

236. Lim HS, Cheng PMY, Chen ATH, et al. Prevalence of cardiac murmurs and acute rheumatic fever in schoolchildren in rural Nepal. Heart Lung Circ. 2007; 16:S68.

237. Rizvi SF, Khan MA, Kundi A, March DR, Samad A, Pasha O. Status of rheumatic heart disease in rural Pakistan. Heart. 2004;90: 394-399.

238. Augestad KM, Martyshova K, Martyshov S, Foederov B, Lie M. Rheumatic fever and rheumatic heart disease in Northwest Russia. Tidsskr Nor Laegeforen. 1999;119:1456-1459.

239. Mendis S, Nasser M, Perera K. A study of rheumatic heart disease and rheumatic fever in a defined population in Sri Lanka. Ceylon J Med Sci. 1998;40:31-37.

240. Schwankhaus JD. Preventing rheumatic heart disease in developing countries. Ann Intern Med. 1994;121:77.

241. McNeil SA, Halperin SA, Langley JM, et al. Safety and immunogenicity of 26-valent group a streptococcus vaccine in healthy adult volunteers. Clin Infect Dis. 2005;41:1114-1122.

242. Gordis L. Effectiveness of comprehensive-care programs in preventing rheumatic fever. N Engl J Med. 1973;289:331-335.

243. Lennon D, Kerdemelidis M, Arroll B. Meta-analysis of trials of streptococcal throat treatment programs to prevent rheumatic fever. Pediatr Infect Dis J. 2009;28:e259-e264.

244. Karthikeyan G, Mayosi BM. Is primary prevention of rheumatic fever the missing link in the control of rheumatic heart disease in Africa? Circulation. 2009;120:709-713.

245. Bryant PA, Robins-Browne R, Carapetis JR, Curtis N. Some of the people, some of the time: susceptibility to acute rheumatic fever. Circulation. 2009;119:742-753.
Clinical Epidemiology

\section{Publish your work in this journal}

Clinical Epidemiology is an international, peer-reviewed, open access journal focusing on disease and drug epidemiology, identification of risk factors and screening procedures to develop optimal preventative initiatives and programs. Specific topics include: diagnosis, prognosis, treatment, screening, prevention, risk factor modification, systematic

\section{Dovepress}

reviews, risk \& safety of medical interventions, epidemiology \& biostatical methods, evaluation of guidelines, translational medicine, health policies \& economic evaluations. The manuscript management system is completely online and includes a very quick and fair peer-review system, which is all easy to use. 